\title{
Oil and gas impacts on air quality in federal lands in the Bakken region: an overview of the Bakken Air Quality Study and first results
}

\author{
A. J. Prenni ${ }^{1}$, D. E. Day ${ }^{2}$, A. R. Evanoski-Cole ${ }^{3}$, B. C. Sive ${ }^{1}$, A. Hecobian ${ }^{3}$, Y. Zhou ${ }^{3}$, K. A. Gebhart ${ }^{4}$, J. L. Hand ${ }^{2}$, \\ A. P. Sullivan ${ }^{3}$, Y. Li ${ }^{3}$, M. I. Schurman ${ }^{3}$, Y. Desyaterik ${ }^{3}$, W. C. Malm ${ }^{2}$, J. L. Collett Jr. ${ }^{3}$, and B. A. Schichtel ${ }^{4}$ \\ ${ }^{1}$ National Park Service, Air Resources Division, Lakewood, CO, USA \\ ${ }^{2}$ Cooperative Institute for Research in the Atmosphere (CIRA), Colorado State University, Fort Collins, CO, USA \\ ${ }^{3}$ Department of Atmospheric Science, Colorado State University, Fort Collins, CO, USA \\ ${ }^{4}$ National Park Service, Air Resources Division, Fort Collins, CO, USA
}

Correspondence to: A. J. Prenni (anthony_prenni@nps.gov)

Received: 11 September 2015 - Published in Atmos. Chem. Phys. Discuss.: 23 October 2015

Revised: 20 January 2016 - Accepted: 21 January 2016 - Published: 8 February 2016

\begin{abstract}
The Bakken formation contains billions of barrels of oil and gas trapped in rock and shale. Horizontal drilling and hydraulic fracturing methods have allowed for extraction of these resources, leading to exponential growth of oil production in the region over the past decade. Along with this development has come an increase in associated emissions to the atmosphere. Concern about potential impacts of these emissions on federal lands in the region prompted the $\mathrm{Na}$ tional Park Service to sponsor the Bakken Air Quality Study over two winters in 2013-2014. Here we provide an overview of the study and present some initial results aimed at better understanding the impact of local oil and gas emissions on regional air quality. Data from the study, along with longterm monitoring data, suggest that while power plants are still an important emissions source in the region, emissions from oil and gas activities are impacting ambient concentrations of nitrogen oxides and black carbon and may dominate recent observed trends in pollutant concentrations at some of the study sites. Measurements of volatile organic compounds also definitively show that oil and gas emissions were present in almost every air mass sampled over a period of more than 4 months.
\end{abstract}

\section{Introduction}

The Williston Basin covers several hundred thousand square kilometers in parts of North Dakota (ND), Montana (MT), South Dakota (SD), Saskatchewan, and Manitoba. In the Bakken and Three Forks formations within the Williston Basin, it is estimated that there are more than 7 billion barrels of recoverable oil (http://www.eia.gov/), making it the largest tight oil play in the United States (US) (EIA, 2014). Despite these vast deposits, it is only in the past decade that horizontal drilling and hydraulic fracturing methods have allowed for cost-efficient extraction of these resources, which has led to exponential growth in the number of wells in the region. Much of this activity is in ND (Fig. 1), where there are currently $\sim 10000$ active wells producing over 1 million barrels of oil each day (https://www.dmr.nd.gov/oilgas/). These numbers are expected to grow, with associated increases in pollutant emissions.

Oil and gas development activities provide potential sources of air pollutants during all stages of well development and resource extraction (Brown et al., 2015; Field et al., 2014; Olaguer, 2012; Roy et al., 2014). Emissions come from a large number of small sources that can vary broadly both in terms of absolute amounts and compositions (Field et al., 2014). A large number of studies have focused on methane emissions (e.g. Brandt et al., 2014; Howarth et al., 2011; Subramanian et al., 2015), and associated greenhouse warming (e.g. Jiang et al., 2011). These issues are particularly sig- 


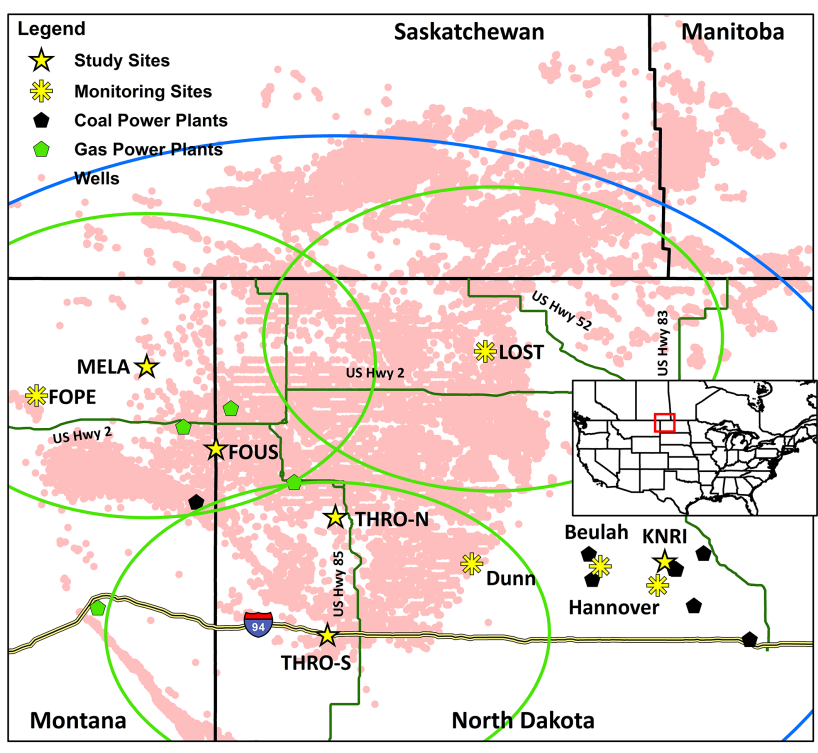

Figure 1. Map of study area, including state monitoring sites and regional power plants. For oil and gas wells, shapefiles were filtered to only include active and/or producing wells. For reference, the blue line represents $250 \mathrm{~km}$ from THRO-N, the distance traveled by an airmass in $48 \mathrm{~h}$, based on the median wind speed at the site during the study. Green lines represent $100 \mathrm{~km}$ distance from THRO-S, LOST, and MELA.

nificant in the Bakken, where it is estimated that methane emissions correspond to leakages of $9.1 \% \pm 6.2 \%$ of energy content (Schneising et al., 2014). Along with methane, other pollutants such as volatile organic compounds (VOCs), including hazardous air pollutants, can be released (Helmig et al., 2014; Olaguer, 2012; Petron et al., 2012; Swarthout et al., 2015). Chemicals used in oil and gas extraction (Colborn et al., 2011) are associated with a wide range of human health hazards, and potential health impacts have been identified for communities near well pads (Bamberger and Oswald, 2015; McKenzie et al., 2012; Steinzor et al., 2013).

There are also emissions from the equipment needed for oil and gas development (Roy et al., 2014), including VOCs, nitrogen oxides $\left(\mathrm{NO}_{x}: \mathrm{NO}+\mathrm{NO}_{2}\right)$, elemental carbon (EC), particulate matter (PM), and sulfur dioxide $\left(\mathrm{SO}_{2}\right)$. In 2011, $\mathrm{NO}_{x}$ emissions in the Williston Basin related to oil and gas activities were estimated at 29400 tons (Grant et al., 2014). $\mathrm{NO}_{x}$ emissions for highway transportation were less than half of this value this same year (EPA National Emissions Inventory), when considering the same counties in the Williston Basin (ND, SD and MT). Emissions of VOCs and $\mathrm{NO}_{x}$ associated with oil and gas extraction can drive elevated ozone concentrations (Olaguer, 2012), which can impact national parks (Rodriguez et al., 2009) and other sensitive areas. High wintertime ozone concentrations have also been associated with oil and gas activities (Ahmadov et al., 2015; Edwards et al., 2014; Helmig et al., 2014; Schnell et al., 2009); however, these wintertime ozone episodes occur during strong inversions, which are not typically observed in the Bakken region.

Support for drilling and operation of active wells has its own associated emissions. For example, in the Marcellus shale region it is estimated that over one thousand diesel trucking events are typical for every new well drilled (Roy et al., 2014). Average traffic counts on Highway 85 in McKenzie County, which runs through the center of the oil and gas activities in the Bakken and is adjacent to the North Unit of Theodore Roosevelt National Park, have more than tripled from 2008 to 2014 (http://www.dot.nd.gov/road-map/ traffic/). Along with increased traffic, increased population to support these activities adds to emissions. The region may also be impacted by pollutants originating in Canada, where there is extensive oil and gas activity regionally (see Fig. 1), as well as potential for long-range transport of pollutants from the Alberta Oil Sands (Bytnerowicz et al., 2010; Howell et al., 2014; Simpson et al., 2010).

Although oil is the primary commodity in the Bakken, there is also a large amount of associated natural gas. However, because the infrastructure to transport this natural gas is still being developed, until recently about one third of this gas was flared. In 2013, this amounted to over 100 billion cubic feet of natural gas flared or vented in ND (http: //www.eia.gov/). These flares add to the pollution burden (Pederstad et al., 2015), producing $\mathrm{CO}_{2}, \mathrm{EC}, \mathrm{CO}$ and $\mathrm{NO}_{x}$, particularly in the Bakken where flare efficiencies (Leahey et al., 2001) may be quite low owing to persistent high winds and the presence of surface and/or pit flares. The percentage of gas that is flared is now declining as a result of new regulations, with proposed limits on flaring of $10 \%$ of produced natural gas by 2020 .

Ambient particle concentrations also can be impacted by oil and gas activities. Increased particle loading has the potential to degrade visibility (Malm et al., 1994), a protected air quality related value in Class I areas, and can cause adverse health effects (e.g. Laden et al., 2006). These particles can be the result of direct emissions, such as fugitive dust from mobile sources (Bar-Ilan et al., 2011), or formed from reactions of precursor species such as $\mathrm{SO}_{2}$, VOCs, and $\mathrm{NO}_{x}$. Monitoring data from the Interagency Monitoring of Protected Visual Environments (IMPROVE) Program suggest that sites in the Bakken region have not experienced the same improvements to air quality as many places in the United states since 2000. Across the region, annual trends in composition for sulfate, nitrate, and EC are generally decreasing (Fig. S1 in Supplement), although within the Bakken trends are mixed and nitrate and sulfate concentrations have increased in the Bakken region during December from 2000 to 2010 (Hand et al., 2012a). Increasing, although statistically insignificant, trends were also observed at IMPROVE sites in the Bakken region on the $20 \%$ haziest days from 2000-2011 (Hand et al., 2014), counter to national trends.

The rapid expansion of the oil and gas sector has the potential to impact four national park units in this region: Fort 
Union Trading Post National Historic Site (NHS) (FOUS), Knife River Indian Villages NHS (KNRI), and the north and south units of Theodore Roosevelt National Park (THRO-N and THRO-S). THRO is a Class I airshed, which provides for the highest level of federal protection of its air quality, while FOUS and KNRI are Class II airsheds. There are also two US Fish and Wildlife Class I areas nearby: Lostwood, ND (LOST) and Medicine Lake, MT (MELA). In 2011, McKenzie County in ND, where THRO-N is located, accounted for the highest emissions of $\mathrm{NO}_{x}, \mathrm{VOCs}, \mathrm{PM}, \mathrm{CO}$, and $\mathrm{SO}_{2}$ from oil and gas in the Williston Basin (Grant et al., 2014), making THRO-N highly vulnerable to impacts from air pollutants related to oil and gas development.

The lack of progress toward the goals of the Regional Haze Rule (EPA, 2003) at THRO and increasing emissions and potential impacts of oil and gas development on air quality in these natural areas prompted the National Park Service to sponsor the Bakken Air Quality Study, carried out in two field deployments in 2013-2014. The locations of the field sites are shown in Fig. 1, as well as the locations of long-term monitoring sites. Here we provide an overview of the measurements and determine their representativeness relative to the historical record. A summary of key results is presented, and we address the question of whether energy development in the Bakken region is impacting air quality in national parks and other federal lands in the region.

\section{Experimental}

\subsection{Study periods}

The Bakken Air Quality Study (BAQS) was conducted to assess the mix of pollutants impacting national parks and Class I areas in the Bakken region. Although elevated pollutant levels can occur anytime of the year, measurements were focused primarily on winter months. The first BAQS study period was in 2013, with measurements from 15 February to 6 April. The study was conducted at five field sites: FOUS, KNRI, MELA, THRO-N and THRO-S. THRO-N served as the core sampling site. At the core site, high time resolution measurements were made of $\mathrm{NO}_{x}, \mathrm{CO}$, Total Reactive Nitrogen, $\mathrm{O}_{3}, \mathrm{SO}_{2}$, black carbon and aerosol light scattering. More extensive data were also obtained at lower time resolution ( $6 \mathrm{~h}-1$ week) of organic and inorganic composition of particles and gases. The other four sites were not as heavily instrumented. FOUS, MELA and KNRI had $48 \mathrm{~h}$ integrated samples (6 days a week) of inorganic gas and particulate composition, real time ozone measurements, automated precipitation samplers and Radiello passive samplers, which measured weekly integrated concentrations of $\mathrm{SO}_{2}, \mathrm{NO}_{2}$, $\mathrm{NH}_{3}$ and $\mathrm{O}_{3}$. A nephelometer was also deployed at KNRI. Because THRO-S is heavily instrumented through state and federal monitoring programs, only passive samplers were deployed at this site. Meteorological data were available at all sites. In addition to the sampling sites, 2 days of measurements of methane and VOCs were made using a mobile laboratory. A detailed list of measurements from the first study period is given in Table 1 .

The second study period ran from 23 November 2013 through 28 March 2014, encompassing the largest increasing trends in sulfate and nitrate as determined from IMPROVE observations (Hand et al., 2012a). During the second study, measurements were limited to three sites, with increased emphasis on higher time resolution data collection. THRO-N remained the core site, while FOUS and MELA served as satellite sites. At THRO-N and FOUS, additional measurements of gas and particle concentrations and compositions were made, including VOC measurements (Table 2). The VOC data provide markers for many of the potential air pollutant sources in this region. Mobile measurements were also conducted (see Sect. 2.2).

These study periods correspond to months when temperatures are typically below freezing, and where minimum winter temperatures can fall below $-30^{\circ} \mathrm{C}$. Based on meteorological data collected during 2002-2013 at Watford City (near THRO-N), MELA, and LOST, the predominant wind direction in the study region was southwesterly and the second most common direction was northwesterly, though airmasses can arrive from all directions. There are spatial, diurnal, and seasonal fluctuations around this predominant pattern. Seasonally, air masses from the northwest are most common during fall and winter; this was generally observed during BAQS. Transport from easterly directions is most likely during spring and summer. Average wind speeds in winter were in the range of $3-5 \mathrm{~m} \mathrm{~s}^{-1}$ at all of the study sites, with Watford City (near THRO-N) having the slowest and LOST the highest mean speeds.

\subsection{Methods}

Many of the measurements listed in Tables 1 and 2 will be described in detail in forthcoming publications, and so are not discussed further. Here we provide a brief description of measurements from the Results and Discussion section.

For real time measurements of $\mathrm{NO}_{x}$ and $\mathrm{SO}_{2}$ during the first study period, sampling was from a common inlet $\sim 3 \mathrm{~m}$ above ground level. The sampling line was $0.64 \mathrm{~cm}$ OD Teflon tubing. For $\mathrm{SO}_{2}$ from the real time measurements, a calibration was performed prior to the study. For $\mathrm{NO}_{x}$, calibrations were conducted daily using certified, traceable standards provided by Airgas (Prenni et al., 2014). Every calibration included zero air and a span concentration, with calibration gases introduced at the sample inlets.

$\mathrm{NO}_{x}$ measurements were made using a chemiluminescence instrument (Teledyne 201E). The technique alternately measures $\mathrm{NO}$ directly and measures $\mathrm{NO}_{x}$ by first converting $\mathrm{NO}_{2}$ to $\mathrm{NO}$ using a molybdenum converter. $\mathrm{NO}$ is reacted with ozone forming $\mathrm{NO}_{2}$ in an excited state which emits radiation while decaying to the ground state. 
Table 1. Measurements from the first field campaign: 15 February-6 April 2013.

\begin{tabular}{|c|c|c|c|c|c|c|c|c|}
\hline $\begin{array}{l}\text { Measurement } \\
\text { method }\end{array}$ & Measured species & $\begin{array}{l}\text { Time resolution of } \\
\text { available data }\end{array}$ & Notes & THRO-S & THRO-N & FOUS & KNRI & MELA \\
\hline $\begin{array}{l}\text { URG annular } \\
\text { denuder/filter- } \\
\text { pack sampler }\end{array}$ & $\begin{array}{l}\mathrm{PM}_{2.5} \text { inorganic } \\
\text { ions; } \mathrm{NH}_{3}, \mathrm{HNO}_{3} \text {, } \\
\text { and } \mathrm{SO}_{2}\end{array}$ & See Sect. 2.2 & $\begin{array}{l}\text { Analysis with Dionex IC } \\
\text { system }\end{array}$ & & $\mathrm{X}$ & $X$ & $\mathrm{X}$ & $X$ \\
\hline $\begin{array}{l}\text { IMPROVE } \\
\text { module A }\end{array}$ & $\begin{array}{l}\mathrm{PM}_{2.5} \text { mass, ele- } \\
\text { mental composition }\end{array}$ & $\begin{array}{l}24 \text { h sample } \\
\text { THRO-N: daily; } \\
\text { Existing: every } \\
3 \text { days }\end{array}$ & Per IMPROVE protocol & Existing & $X$ & & & Existing \\
\hline $\begin{array}{l}\text { Teledyne } \mathrm{O}_{3} \text { or } \\
\text { portable ozone } \\
\text { monitors (POMs) }\end{array}$ & Ozone & $\begin{array}{l}\text { Teledyne: } 1 \mathrm{~min} \\
\text { POMS: } 1 \mathrm{~h}\end{array}$ & $\begin{array}{l}\text { Teledyne 400E at THRO-N; } \\
\text { 2B Technologies at other sites }\end{array}$ & Existing & $X$ & $\mathrm{X}$ & $\mathrm{X}$ & $\mathrm{X}$ \\
\hline $\begin{array}{l}\text { Continuous } \\
\text { gaseous samplers }\end{array}$ & $\begin{array}{l}\mathrm{NO}_{x}, \quad \mathrm{NO}, \quad \mathrm{NO}_{2} \\
\mathrm{SO}_{2}, \mathrm{CO}\end{array}$ & $1 \mathrm{~min}$ & See Sect. 2.2 & & $\mathrm{X}$ & & & \\
\hline $\begin{array}{l}\text { Automated } \\
\text { precipitation } \\
\text { (rain/snow) } \\
\text { sampler }\end{array}$ & Wet Deposition & $\begin{array}{l}\text { THRO-N: Samples } \\
\text { collected daily; } \\
\text { Satellite Sites: } \\
\text { Twice per week }\end{array}$ & $\begin{array}{l}\text { NCON Atmospheric Deposition } \\
\text { Sampler/ National Trends Net- } \\
\text { work (ADS/NTN); } \\
\text { Yankee Envir. TPC } 3000\end{array}$ & Existing & $\mathrm{X}$ & $\mathrm{X}$ & $\mathrm{X}$ & $\mathrm{X}$ \\
\hline Nephelometer & $\begin{array}{l}\text { Particle light scat- } \\
\text { tering }\end{array}$ & $5 \mathrm{~min}$ & $\begin{array}{l}\text { THRO-N: Radiance Research; } \\
\text { KNRI: Ecotech }\end{array}$ & & $\mathrm{X}$ & & $\mathrm{X}$ & \\
\hline Aethalometer & Black Carbon & $5 \mathrm{~min}$ & Magee Scientific 7 wavelength & & $\mathrm{X}$ & & & \\
\hline Passive samplers & $\begin{array}{l}\mathrm{SO}_{2}, \quad \mathrm{NO}_{2}, \quad \mathrm{NH}_{3} \\
\text { and } \mathrm{O}_{3}\end{array}$ & 1 week & Radiello & $\mathrm{X}$ & $\mathrm{X}$ & $X$ & $\mathrm{X}$ & $\mathrm{X}$ \\
\hline $\begin{array}{l}\text { Meteorological } \\
\text { station }\end{array}$ & $\begin{array}{l}\text { Surface meteorol- } \\
\text { ogy }\end{array}$ & $\begin{array}{l}1 \mathrm{~min} \text { at THRO-N } \\
\text { and FOUS }\end{array}$ & $\begin{array}{l}\text { Climatronics All-In-One Weather } \\
\text { Sensor }\end{array}$ & Existing & $X$ & $X$ & Existing & Existing \\
\hline Mobile Sampling & $\begin{array}{l}\text { Methane and acety- } \\
\text { lene }\end{array}$ & $3 \mathrm{~Hz}$ & $\begin{array}{l}\text { Picarro G2203 with mobile kit } \\
\text { A0941 }\end{array}$ & & & & & \\
\hline
\end{tabular}

Real time $\mathrm{SO}_{2}$ measurements were made during the first study period using a Thermo Scientific $\mathrm{SO}_{2}$ Analyzer (Model 43C), which uses pulsed fluorescence and has a detection limit of $1 \mathrm{ppbv}$ ( $60 \mathrm{~s}$ averaging). During the second study period, and during both studies at the satellite sites, $\mathrm{SO}_{2}$ concentrations were also derived from University Research Glassware (URG) samplers.

Twenty-four hour samples were collected using URG annular denuder/filter-pack samplers from 8 a.m. to 8 a.m. local time at THRO-N during both study periods. During the first study period, $48 \mathrm{~h}$ samples were also collected at FOUS, MELA and KNRI, covering 6 days per week. During the second study, $24 \mathrm{~h}$ samples were collected at FOUS, and weekly samples were collected at MELA. Extracted samples were analyzed for inorganic gas and particulate species using ion chromatography (IC). Sample collection and analysis procedures were similar to those described elsewhere (Benedict et al., 2013).

Real time black carbon (BC) data were collected using a multi-wavelength aethalometer at the core site (Magee Scientific AE-31). We follow the recommendation of Petzold et al. (2013) in designating aethalometer measurements as BC and measurements from the IMPROVE program as EC. The sample is collected on quartz fiber filter tape and absorption is measured at seven wavelengths from $370-950 \mathrm{~nm}$. For this study, a $\mathrm{PM}_{2.5}$ inlet was used and $\mathrm{BC}$ mass was determined as the mean of the masses measured from all wavelengths; no further corrections were implemented. Aethalometer data were logged as $5 \mathrm{~min}$ averages. The instrument was factory calibrated prior to the first study period and has a sensitivity of $<0.1 \mu \mathrm{g} \mathrm{m}^{-3}$.

The THRO-N site also had an IMPROVE particle monitor that collected $24 \mathrm{~h}$ samples. Samples were collected daily, on the same schedule as the URG samplers ( 8 a.m. to 8 a.m.). Modules A, C, and D were used during the study. Modules $\mathrm{A}$ and $\mathrm{C}$ collect fine particles $\left(\mathrm{PM}_{2.5}\right)$, while module $\mathrm{D}$ collects both fine and coarse particles $\left(\mathrm{PM}_{10}\right)$. Module A is equipped with a Teflon ${ }^{\circledR}$ filter that is analyzed for $\mathrm{PM}_{2.5}$ gravimetric fine mass, elemental concentration, and light absorption. Module $\mathrm{C}$ utilizes a quartz fiber filter that is analyzed by thermal optical reflectance (TOR) for organic carbon and EC. Module D utilizes a Teflon filter to determine $\mathrm{PM}_{10}$ aerosol mass concentrations gravimetrically. Module A was used during the first study, and Modules A and C were used during the second study period. Module D was used for a limited time during the second measurement period.

For VOC measurements, whole air samples were collected at THRO-N, FOUS, and MELA, as well as at various locations throughout the Bakken region as part of the mobile measurements. During the second study period, samples were collected into evacuated $2 \mathrm{~L}$ passivated, stainless steel canisters. A total of 40 individual VOCs were quantified from the canister samples using a five-channel, three gas chromatograph (GC) analytical system which employed three flame ionization detectors (FIDs), one electron capture detector (ECD) and one mass spectrometer (MS). The gases analyzed included $\mathrm{C}_{2}-\mathrm{C}_{10}$ nonmethane hydrocarbons (NMHCs), $\mathrm{C}_{1}-\mathrm{C}_{2}$ halocarbons, $\mathrm{C}_{1}-\mathrm{C}_{5}$ alkyl nitrates and re- 
Table 2. Measurements from the second field campaign: 23 November 2013-28 March 2014.

\begin{tabular}{|c|c|c|c|c|c|c|c|c|}
\hline Measurement method & Measured species & $\begin{array}{l}\text { Time resolution of available } \\
\text { data }\end{array}$ & Notes & THRO-S & THRO-N & FOUS & KNRI & MELA \\
\hline $\begin{array}{l}\text { URG annular } \\
\text { denuder/filter-pack } \\
\text { sampler }\end{array}$ & $\begin{array}{l}\mathrm{PM}_{2.5} \text { inorganic ions; } \\
\mathrm{NH}_{3}, \mathrm{HNO}_{3} \text {, and } \mathrm{SO}_{2}\end{array}$ & See Sect. 2.2 & Analysis with Dionex IC system & & $\mathrm{X}$ & $\mathrm{X}$ & & $\mathrm{X}$ \\
\hline IMPROVE module A & $\begin{array}{l}\mathrm{PM}_{2.5} \text { mass, elemental } \\
\text { composition }\end{array}$ & $\begin{array}{l}24 \text { h sample } \\
\text { THRO-N: daily; } \\
\text { Existing: every } 3 \text { days }\end{array}$ & Per IMPROVE protocol & Existing & $\mathrm{X}$ & & & Existing \\
\hline IMPROVE module $\mathrm{C}$ & $\mathrm{PM}_{2.5} \mathrm{OC}$ and $\mathrm{EC}$ & $\begin{array}{l}24 \text { h sample } \\
\text { THRO-N: daily; } \\
\text { Existing sites: every } 3 \text { days }\end{array}$ & Per IMPROVE protocol & Existing & $\mathrm{X}$ & & & Existing \\
\hline $\begin{array}{l}\text { Aerosol Mass Spec- } \\
\text { trometer }\end{array}$ & $\begin{array}{l}\mathrm{PM}_{1} \text { nitrate, sulfate, } \\
\text { ammonium, organics }\end{array}$ & $5 \mathrm{~min}$ & $\begin{array}{l}\text { Aerodyne High Resolution Time } \\
\text { of Flight }\end{array}$ & & $\mathrm{X}$ & & & \\
\hline $\begin{array}{l}\text { MARGA (Monitor for } \\
\text { Aerosol and Gases) }\end{array}$ & $\begin{array}{l}\mathrm{PM}_{2.5} \text { Inorganic ions; } \\
\text { Gaseous } \mathrm{NH}_{3}, \mathrm{HNO}_{3} \text {, } \\
\text { and } \mathrm{SO}_{2}\end{array}$ & $1 \mathrm{~h}$ & Applikon 1S & & $\mathrm{X}$ & & & \\
\hline $\begin{array}{l}\text { Teledyne } \mathrm{O}_{3} \text { or } \\
\text { portable ozone moni- } \\
\text { tors (POMs) }\end{array}$ & Ozone & $\begin{array}{l}\text { Teledyne: } 1 \mathrm{~min} \\
\text { POMS: } 1 \mathrm{~h}\end{array}$ & $\begin{array}{l}\text { Teledyne } 400 \mathrm{E} \text { at THRO-N; } \\
\text { 2B Technologies at other sites }\end{array}$ & Existing & $\mathrm{X}$ & $\mathrm{X}$ & & $\mathrm{X}$ \\
\hline $\begin{array}{l}\text { Continuous gaseous } \\
\text { samplers }\end{array}$ & $\begin{array}{l}\mathrm{NO}_{x}, \mathrm{NO}, \mathrm{NO}_{2}, \mathrm{CO}, \\
\mathrm{NO}_{y}\end{array}$ & $1 \mathrm{~min}$ & See Sect. 2.2 & & $\mathrm{X}$ & & & \\
\hline $\begin{array}{l}\text { Automated precipita- } \\
\text { tion (rain/snow) sam- } \\
\text { pler }\end{array}$ & Wet Deposition & $\begin{array}{l}\text { THRO-N: Samples Col- } \\
\text { lected after precipitation }\end{array}$ & NCON ADS/NTN Sampler & Existing & $\mathrm{X}$ & & & \\
\hline Nephelometer & Particle light scattering & $5 \mathrm{~min}$ & $\begin{array}{l}\text { THRO-N: Radiance Research; } \\
\text { FOUS: Optec; } \\
\text { MELA: Ecotech }\end{array}$ & & $\mathrm{X}$ & $\mathrm{X}$ & & $\mathrm{X}$ \\
\hline Aethalometer & Black Carbon & $5 \mathrm{~min}$ & Magee Scientific 7 wavelength & & $\mathrm{X}$ & & & \\
\hline TEOM & $\mathrm{PM}_{2.5}$ Mass & $6 \min$ & Thermo Scientific 1405-DF & & $\mathrm{X}$ & & & \\
\hline VOC canisters & VOCs & $\begin{array}{l}\text { THRO-N: Twice per day; } \\
\text { FOUS: } 4 \text { times per week; } \\
\text { MELA: once per week }\end{array}$ & $\begin{array}{l}\text { Analysis with 5-channel GC sys- } \\
\text { tem; FID, ECD and MS }\end{array}$ & & $\mathrm{X}$ & $\mathrm{X}$ & & $\mathrm{X}$ \\
\hline $\begin{array}{l}\text { Proton Transfer } \\
\text { Reaction-Quadrupole } \\
\text { Mass Spectrometer } \\
\text { (PTR-QMS) }\end{array}$ & VOCs & $\begin{array}{l}1-5 \mathrm{~min} \\
\text { Data available for } \\
\sim 5 \text { weeks of the study }\end{array}$ & $\begin{array}{l}\text { Ionic Analytik; Measurement site } \\
\text { not collocated with core site mea- } \\
\text { surements }\end{array}$ & & $\mathrm{X}$ & & & \\
\hline Meteorological station & Surface meteorology & $\begin{array}{l}1 \text { min at THRO-N and } \\
\text { FOUS }\end{array}$ & $\begin{array}{l}\text { Climatronics All-In-One Weather } \\
\text { Sensor }\end{array}$ & & $\mathrm{X}$ & $\mathrm{X}$ & & Existing \\
\hline Mobile Measurements & $\begin{array}{l}\text { VOC canisters; mini- } \\
\text { aethalometer; neph- } \\
\text { elometer; acetylene; } \\
\text { methane }\end{array}$ & $\begin{array}{l}\text { Canisters: Grab Samples; } \\
\text { MicroAeth: } 1 \mathrm{~min} \text {; } \\
\text { Picarro: } 3 \mathrm{~Hz} \text {; } \\
\text { Neph: } 5 \mathrm{~s}\end{array}$ & $\begin{array}{l}\text { AethLabs MicroAeth AE51; } \\
\text { Radiance Research Nephelome- } \\
\text { ter; } \\
\text { Picarro G2203 with mobile kit } \\
\text { A0941 }\end{array}$ & & & & & \\
\hline
\end{tabular}

duced sulfur compounds. The analytical system and methodology are similar to those used in previous studies (Russo et al., 2010a, b; Sive, 1998; Swarthout et al., 2013, 2015; Zhou et al., 2010). Multiple whole air standards were used during sample analysis (analyzed every 10 samples). The measurement precision, represented by the relative standard deviation of the peak areas for each compound in the whole air standards, was $1-8 \%$ for the NMHCs, $3-10 \%$ for the halocarbons, 3-8\% for the alkyl nitrates and 3-5\% for the sulfur compounds. For the second study period, a canister sample was collected twice per day at THRO-N, four times per week at FOUS, and once per week at MELA. For approximately 1 month of the study (19 December 2013-31 January 2014), canisters were collected only once per week at FOUS.

Meteorological data were collected with a Climatronics All-In-One Weather Sensor (Part Number 102780), colocated with the gas measurements.

\section{Mobile measurements}

A Picarro A0941 mobile measurement kit combined with a Picarro G2203 analyzer was deployed inside a Chevrolet Tahoe Hybrid vehicle for mobile measurements of $\mathrm{CH}_{4}$ and $\mathrm{C}_{2} \mathrm{H}_{2}$. The Tahoe SUV was deployed three times during BAQS for measurements of ambient concentrations of $\mathrm{CH}_{4}$ and $\mathrm{C}_{2} \mathrm{H}_{2}$ near oil and gas activities, encompassing both study periods. Mobile nephelometer and BC data were collected during the second study period. Whole air canister grab samples also were collected and analyzed for VOCs as part of the mobile measurements in March 2014. Mobile measurements were conducted while driving $\sim 50 \mathrm{~km}$ per hour on mostly main roads throughout the Bakken region. Measurement locations were chosen to represent a combination of areas of high oil and gas activity and locations where little or no oil and gas activities were present. When elevated concentrations of $\mathrm{CH}_{4}$ were observed, nearby upwind sources were investigated. When a source was con- 

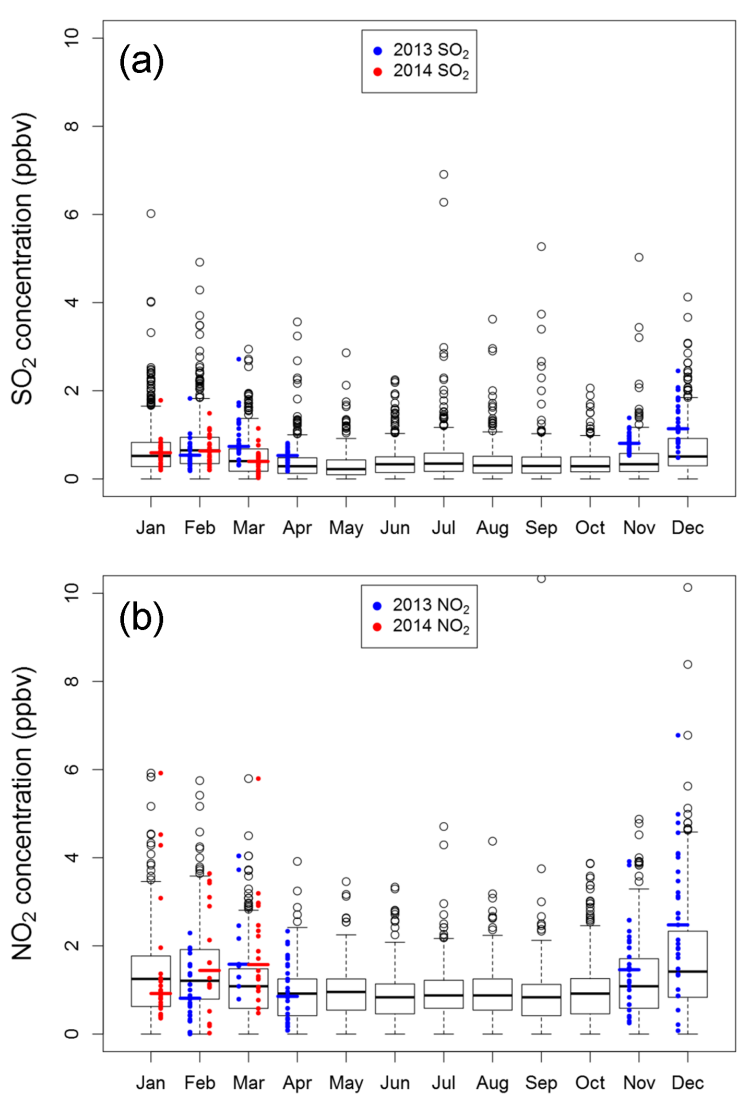

Figure 2. Box plots of daily mean concentrations for (a) $\mathrm{SO}_{2}$ and (b) $\mathrm{NO}_{2}$ at THRO-N, shown in black, for all data available from these sites dating back to 2000 . Also shown are daily averaged data collected during the study periods in 2013 and 2014, with median concentrations shown as horizontal line segments.

firmed, based on elevated methane concentrations and wind direction, the vehicle was stopped and measurements were made downwind of the site. For the measurements in this manuscript, no vehicular traffic was observed within the operator's visual range.

A detailed description of the Picarro analyzer is presented by Mønster et al. (2014). Briefly, a Cavity Ringdown Spectroscopy (CRDS) instrument was used to quantify ambient concentrations of $\mathrm{CH}_{4}$ and $\mathrm{C}_{2} \mathrm{H}_{2}$. The inlet of the system was located on a mast secured in front of the vehicle, at a height of $3 \mathrm{~m}$. Teflon tubing was used to direct the airflow from the inlet to the analyzer at 5 LPM. The A0941 mobile unit was equipped with a Climatronics sonic anemometer for wind speed and direction and a GPS unit for location. Data were collected at $3 \mathrm{~Hz}$.

A microAeth Model AE51 (AethLabs) with a measurement wavelength of $880 \mathrm{~nm}$ was used for measuring ambient concentrations of BC. A more detailed description and characterization of the microAeth is presented by Cai et al. (2014). One minute data were collected at a flow of $200 \mathrm{ccm}$. The microAeth inlet was comprised of black con- ductive tubing ( $\sim 20 \mathrm{~cm}$ long) which was located outside of the back passenger side window of the Tahoe SUV.

\section{Results and discussion}

The objectives of the field studies were to provide initial information on the composition and properties of particulate and gaseous pollutants in national park units in the region and at MELA, a Class 1 US Fish and Wildlife area. In this paper we take a broad look at measurements from the study and explore the representativeness of the study time period. We also provide some highlights from the study, with a focus on measurements of $\mathrm{NO}_{x}, \mathrm{SO}_{2}, \mathrm{EC} / \mathrm{BC}$ and some VOCs, all primary emissions from the energy industry, and address the question of whether energy development in the Bakken is impacting air quality in national parks and other federal lands in the region. More detailed results from all of the measurements, as well as source apportionment, will be presented in forthcoming publications.

\subsection{Study representativeness}

Before presenting measurements from these studies, we first examine monitoring data during the two time periods of the intensive field campaigns to determine if the measurement periods were typical for the region. To this end, we use long-term air monitoring data from the region (EPA AirData: https://ofmext.epa.gov/AQDMRS/aqdmrs.html). In Fig. 2, box plots of mean daily values of $\mathrm{SO}_{2}$ and $\mathrm{NO}_{2}$ concentrations at THRO-N are presented for all available data since 2000. Data are also shown separately for each month of the BAQS study periods. As shown in Fig. 2, there was significant variability for $\mathrm{SO}_{2}$ and $\mathrm{NO}_{2}$ during the study periods; e.g. daily average concentrations of $\mathrm{NO}_{2}$ ranged from near zero to $7 \mathrm{ppbv}$. March and December 2013 showed elevated concentrations of both species at THRO-N, with median values for both months falling above the 75th percentile, and December 2013 having the highest median concentrations for each of these species during the two intensive study periods. Using the Wilcoxon Rank Sum test, we determined that March and December 2013 were the only 2 months during the studies in which $\mathrm{NO}_{2}$ and $\mathrm{SO}_{2}$ were both significantly greater than the historical data $(p<0.05)$. To better understand the cause for the elevated concentrations, hourly ensemble back trajectories with a maximum length of 5 days were generated using version 4.9 of the Hybrid SingleParticle Lagrangian Integrated Trajectory (HYSPLIT) model (Draxler and Hess, 1998), as shown in Fig. 3 for $\mathrm{NO}_{2}$ data collected during the two study periods. Gridded meteorological data from the $12 \mathrm{~km}$ North American Mesoscale Model (NAM12, http://www.emc.ncep.noaa.gov/NAM/.php) (Janjić, 2003) were used as input. During the study period, back trajectory analysis showed that the periods with highest concentrations (top $5 \%$ ) for $\mathrm{SO}_{2}$ and $\mathrm{NO}_{2}$ corresponded to tra- 

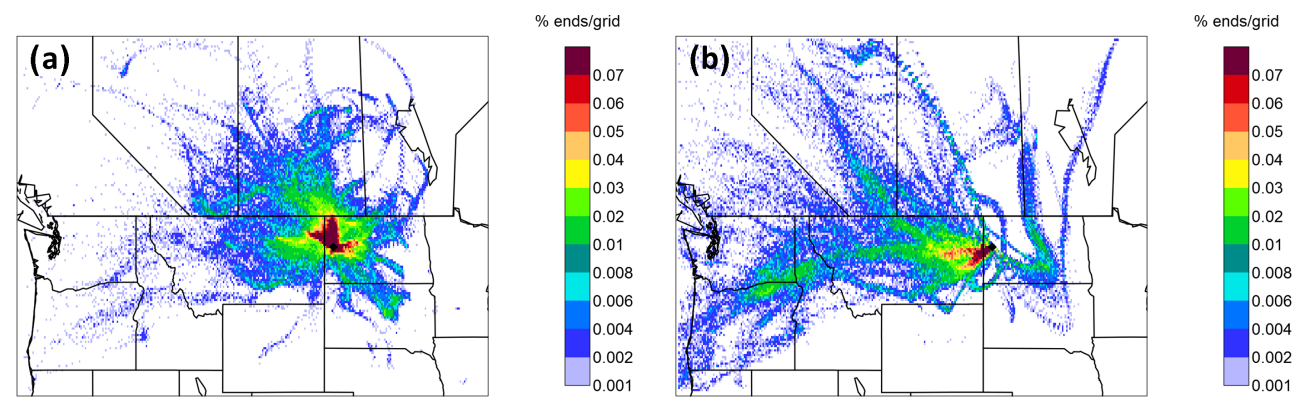

Figure 3. Back trajectory residence times showing areas where air masses resided during the 2 days prior to arriving at THRO-N. (a) Trajectories arriving when the hourly $\mathrm{NO}_{2}$ concentration was at the 95 th percentile $(4.63 \mathrm{ppb})$ or higher for the two Bakken Studies combined. (b) Trajectories arriving when the hourly $\mathrm{NO}_{2}$ concentration was at the 5 th percentile $(0.57 \mathrm{ppb})$ or lower for the combined measurements from both studies. Trajectories were generated using the Hysplit Model in ensemble mode with a start height of $10 \mathrm{~m}$. All trajectories have a duration of 2 days, so longer lengths correspond to higher wind speeds. Note that transport patterns associated with the highest concentrations tend to arrive from a smaller area, indicating probable stagnation, while those associated with the lowest concentrations correspond to travel from more distant areas, indicating high wind speeds, and are more predominantly from the west.

jectories that were shorter (slower speeds) and were more likely to be impacted by closer sources. In contrast, the lower concentration days had higher wind speeds and winds were preferentially from the west.

Although $\mathrm{NO}_{2}$ and $\mathrm{SO}_{2}$ were significantly higher at THRO-N in March and December 2013, EC concentrations from the IMPROVE network (http://views.cira.colostate.edu/ fed/; Malm et al., 1994) at THRO-S were not elevated relative to historical data (Fig. S2). EC typically peaks in summer, when wildfires influence much of the west. Further, THRO$\mathrm{S}$ is at the southern end of the oil and gas fields and winds at THRO-S are primarily out of the northwest and south, so that THRO-S may be less influenced by oil and gas emissions. Comparing EC concentrations across the region during the study period, we observed an increase in EC in going from THRO-S northward to THRO-N and LOST (discussed further below). Thus aerosol concentrations at THRO-S may be driven more by regional reductions in particulate matter (Fig. S1), while sites farther north appear to be impacted by local sources. Considering both THRO-N and THRO-S measurements, we find no instances from the two study periods when the median values for all three species fell outside of the interquartile range, indicating that regionally the study periods were not anomalous relative to past years.

\subsection{Changing emissions and impacts on regional air quality}

Across the United States, emissions from power plants have decreased dramatically in recent decades as the result of legislatively mandated controls, leading to broad improvements in air quality (Hand et al., 2014; Rieder et al., 2013; Sickles II and Shadwick, 2015). In the region surrounding the Bakken, annual power plant $\mathrm{SO}_{2}$ emissions have decreased four-fold over the past 20 years and $\mathrm{NO}_{x}$ emissions have been cut in half (http://ampd.epa.gov/ampd/). At the

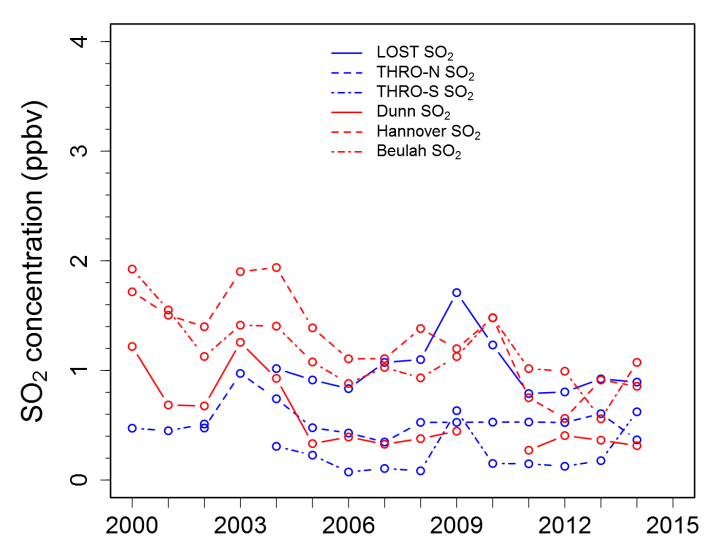

Figure 4. $\mathrm{SO}_{2}$ monitoring data from the EPA AirData website. Data are annually averaged. Missing data points are for years which had less than $50 \%$ of the possible data.

same time, the number of producing oil and gas wells in the ND Bakken region increased by nearly a factor of 50 (https://www.dmr.nd.gov/oilgas/) from January 2005 to January 2015. To better understand the impact of these changing emissions, we again use long-term monitoring data.

Figure 4 shows annually averaged $\mathrm{SO}_{2}$ concentrations collected from monitoring sites at six locations in western ND (EPA AirData; Fig. 1). THRO-N, THRO-S, and LOST all fall within the area with oil and gas activities, although, as noted above, THRO-S may be influenced more by regional trends than local sources. Dunn falls on the outskirts of the Bakken region. Beulah and Hannover both lie to the east of most of the activity, near KNRI and several coal-fired power plants (see Fig. 1), which represent major sources of $\mathrm{SO}_{2}$ in the region. As shown in Fig. 4, $\mathrm{SO}_{2}$ concentrations are declining throughout the region, particularly at sites closer to the power plants, consistent with observations in the eastern United States (Sickles II and Shadwick, 2015; Hand et 


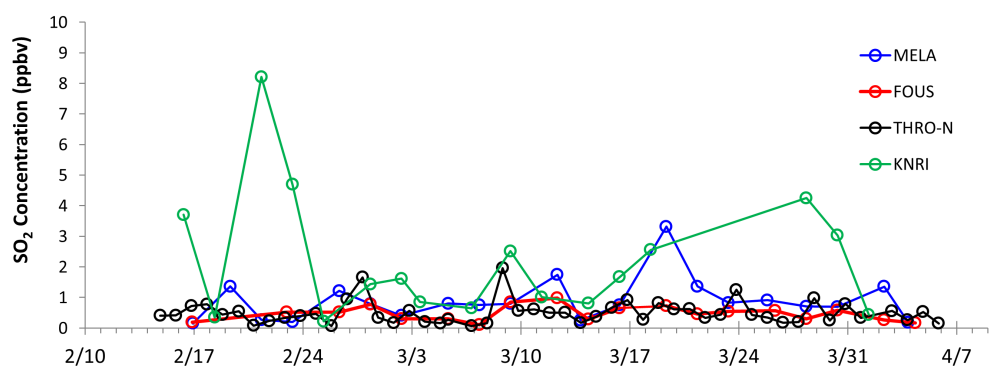

Figure 5. URG measurements of $\mathrm{SO}_{2}$ from all of the field sites during the first study period.
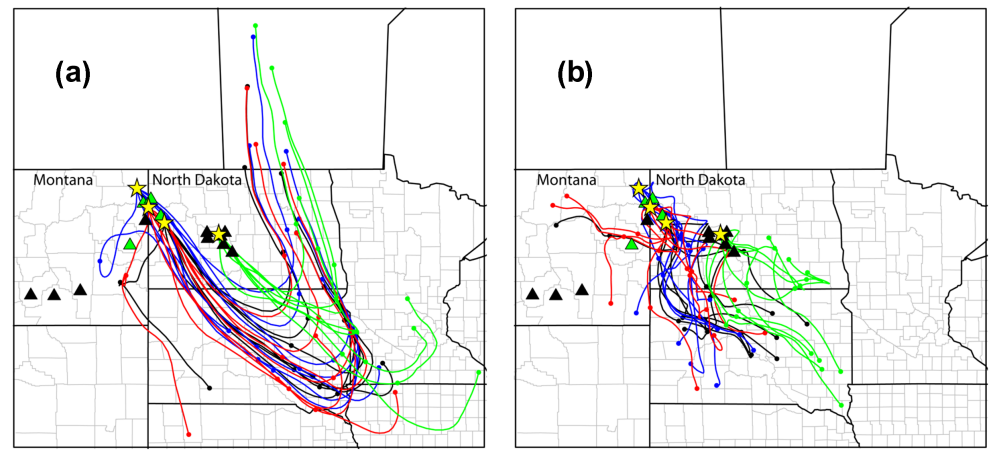

Figure 6. $48 \mathrm{~h}$ back trajectories from THRO-N (black), MELA (blue), FOUS (red) and KNRI (green) for (a) 20-22 February, 8 a.m. to 8 a.m.; and (b) 27-29 March, 8 a.m. to 8 a.m. Back trajectories were run four times per day. Each dot designates a $24 \mathrm{~h}$ period. Field sites are shown as gold stars. Power plants are shown as triangles, with black triangles representing coal-powered plants, and green triangles representing gas-powered plants.

al., 2012b) and decreasing $\mathrm{SO}_{2}$ emissions from power plants across the United States. These reductions were determined to be significant at all of the sites in Fig. 4 except LOST and THRO-N using the Theil-Sen method (Sen, 1968; Theil, 1950) for trend analysis $(p<0.001$; monthly averaged values). Trend analysis throughout the paper was conducted using the Open Air package in R (Carslaw and Ropkins, 2012; Carslaw, 2014).

Despite these reductions, power plants still represent a large source of $\mathrm{SO}_{2}$ in the region, exceeding that from oil and gas development (http://ampd.epa.gov/ampd/; Grant et al., 2014). The influence of $\mathrm{SO}_{2}$ emissions from regional power plants was observed during BAQS on multiple occasions. In Fig. 5, $\mathrm{SO}_{2}$ concentrations from the URG samplers at four sites are shown for the first study period. Data are presented based on the time resolution at which they were collected ( 24 or $48 \mathrm{~h}$ samples). Data collected using the real time $\mathrm{SO}_{2}$ instrument at THRO-N were compared to the URG data, and showed reasonable agreement averaging over the same time periods (not shown; $R^{2}=0.87$; real time instrument produced higher values, slope $=1.19$ ). Apparent in the figure are the higher concentrations observed at KNRI, which is located east of the Bakken and very near several power plants (Fig. 1). We focus on two high $\mathrm{SO}_{2}$ events at KNRI during the first measurement campaign: 20-22 Febru- ary 2013 (8 a.m. to 8 a.m.) and 27-29 March 2013 (8 a.m. to 8 a.m.). On 20-22 February, $48 \mathrm{~h}$ average concentrations at KNRI were $\sim 8 \mathrm{ppbv}$, the highest concentrations observed during the study. During this event, none of the other sites had elevated $\mathrm{SO}_{2}$. Comparing back-trajectories for each of the sites, we see that the air masses which impacted KNRI during this 2-day period passed directly over several coalfired power plants (Fig. 6a), while the air masses reaching the other sites had very little influence from these same plants. Further, the air masses which reached THRO-N during this time period spent minimal time in the Bakken region, and $\mathrm{NO}_{x}$ and $\mathrm{BC}$ concentrations at THRO-N were relatively low during this event (Fig. 7).

During the episode on 27-29 March slower moving air masses with changing wind directions impacted THRO-N, as well as FOUS and MELA, and the airmasses spent more time over the Bakken region (Fig. 6b), yielding considerably higher concentrations of $\mathrm{NO}_{x}$ and $\mathrm{BC}$ at the core site (Fig. 7). However, the air masses which reached THRO-N had only a minor influence from emissions sources east of the Bakken, and $\mathrm{SO}_{2}$ concentrations were again low. While THRO-N, MELA and FOUS were minimally impacted by power plants, KNRI was impacted by several plants on these dates, and KNRI had elevated $\mathrm{SO}_{2}$ concentrations at this time (Fig. 5). These observations are consistent with regional 


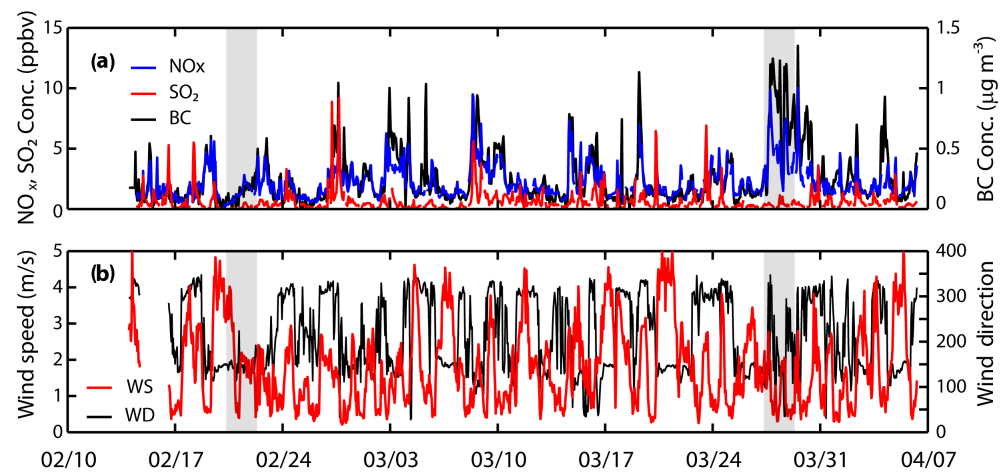

Figure 7. Measurements during the first study period (February-April 2013) at THRO-N of hourly averaged (a) $\mathrm{NO}_{x}(\mathrm{blue}), \mathrm{SO}_{2}(\mathrm{red})$, and BC (black); and (b) wind speed (red) and wind direction (black). Shaded areas indicate time periods discussed in the text and shown in Fig. 6.

power plants largely influencing $\mathrm{SO}_{2}$ concentrations, and emissions sources from within the Bakken, likely tied to the many sources associated with oil and gas activities, leading to the observed increases in $\mathrm{NO}_{x}$ and $\mathrm{BC}$.

Long-term monitoring data for $\mathrm{NO}_{2}$ (EPA AirData) are consistent with these observations and provide an interesting contrast to $\mathrm{SO}_{2}$. Like $\mathrm{SO}_{2}, \mathrm{NO}_{2}$ concentrations have decreased in Hannover and Beulah (Fig. 8), east of the Bakken region ( $p<0.001$; Theil-Sen method, monthly averaged values), likely driven by decreasing $\mathrm{NO}_{x}$ emissions from power plants. In contrast, THRO-N and Dunn, within and at the outskirts of the oil and gas production region, show no significant trends when considering the entire time period shown. However, when limiting the data to the past 10 years (20052014), when oil and gas activities intensified, significant increasing trends in $\mathrm{NO}_{2}$ are observed at both THRO-N and Dunn $(p<0.001$; Theil-Sen method, monthly averaged values). Finally, LOST shows a significant $(p<0.001$; TheilSen method, monthly averaged values) trend of increasing $\mathrm{NO}_{2}$ throughout the time period shown. These changes are consistent with increasing $\mathrm{NO}_{x}$ emissions from oil and gas activities, which more than doubled in the Williston Basin from 2009 to 2011 and are expected to continue to increase (Grant et al., 2014). Unlike $\mathrm{SO}_{2}, \mathrm{NO}_{x}$ emissions from oil and gas are similar in magnitude to those from regional power plants (Grant et al., 2014; http://ampd.epa.gov/ampd/). Trends of increasing $\mathrm{NO}_{2}$ have also been observed in the Marcellus Shale region (Carlton et al., 2014) and the Canadian Oil Sands (McLinden et al., 2012), with increases corresponding to increased activities related to oil and gas extraction.

To further explore the influence of oil and gas emissions, we consider monitoring data at LOST. Focusing on $\mathrm{NO}_{2}$ and segregating measurements by local wind direction, we find significant $(p<0.01$; Theil-Sen method, monthly averaged values) trends of increasing $\mathrm{NO}_{2}$ only when winds are out of the W, SW and S (Fig. 9), areas with major oil and gas development. EC concentrations from IMPROVE, which have many of the same sources as $\mathrm{NO}_{2}$, showed an identical pat-

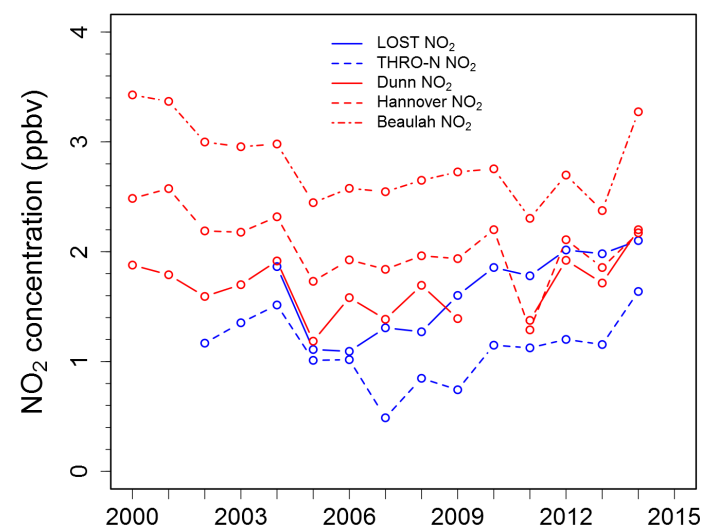

Figure 8. $\mathrm{NO}_{2}$ monitoring data from the EPA AirData website. Data are annually averaged. Missing data points are for years which had less than $50 \%$ of the possible data.

tern. In contrast, the only significant trend for $\mathrm{SO}_{2}$ at LOST is for winds out of the south, where concentrations have decreased, likely from decreasing power plant emissions.

\subsection{Oil and gas impacts on regional air quality}

To better establish a connection between measured pollutants at the study sites and regional oil and gas activities, we consider data from the second study period, 23 November 2013-28 March 2014. These measurements included the use of canisters to collect air samples for analysis of key tracer species. Of particular interest for the Bakken are the light alkanes, which serve as markers for oil and gas activity (e.g. Gilman et al., 2013; Petron et al., 2012; Swarthout et al., 2013, 2015). Figure 10 summarizes measurements of ethane, propane, $\mathrm{n}$-butane, and n-pentane throughout the campaign at all three sites. The mean ethane and propane mixing ratios from all three sites were 16 and $15 \mathrm{ppbv}$, respectively, with maximum values approaching $100 \mathrm{ppbv}$ for ethane and $150 \mathrm{ppbv}$ for propane. The i-butane levels ranged from $0.1-$ $22 \mathrm{ppbv}$, and n-butane peaked over $60 \mathrm{ppbv}$. The i-pentane 


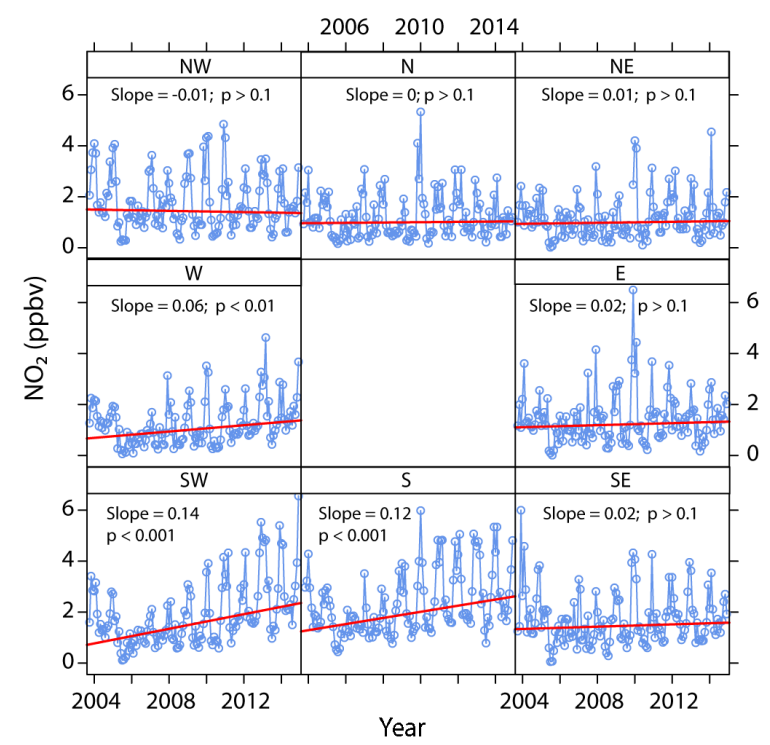

Figure 9. Trends in $\mathrm{NO}_{2}$ data from Lostwood, segregated by wind direction. Slope is per year.

and n-pentane had comparable mixing ratios with mean concentrations of $\sim 1.2 \mathrm{ppbv}$ (range $<0.1-17 \mathrm{ppbv}$ ). These concentrations are significantly higher than typically observed in remote regions (Russo et al., 2010b) and are comparable to levels observed in urban areas known to be influenced by petrochemical industry emissions, as has been observed in other oil and gas basins (Swarthout et al., 2013, 2015). Despite variability in absolute concentrations throughout the study, these data provide evidence that emissions related to oil and gas activities were observed at THRO-S, FOUS, and MELA during the second study period.

To better characterize the extent of this impact, we focus on pentane measurements from all of the sites. Recent studies have used the ratio of pentane isomers to identify air masses that are influenced by oil and gas emissions. Although this ratio varies by basin, a ratio of i-pentane to $n$-pentane which falls at or below one is generally indicative of oil and gas emissions (Swarthout et al., 2013, 2015; Gilman et al., 2013), whereas higher ratios correspond to background conditions, largely resulting from automobile emissions and fuel evaporation (e.g. Russo et al., 2010b). The i-pentane to n-pentane ratios for all sites for the entire sampling period are shown in Fig. 11; the slope is 0.77. Although there is scatter in the data, particularly at the lowest concentrations; only two out of 287 samples at THRO-N, FOUS and MELA had i-pentane to n-pentane ratios that were consistent with background air; all other samples indicated oil and gas influence. These data not only confirm that oil and gas emissions are impacting the region, but also that this influence was present at nearly all times during the second study period.

Mobile measurements collected throughout the Bakken region support these data. Background concentrations for $\mathrm{CH}_{4}$ observed in the Bakken region for the sampling period of 10-16 December 2013 were $2.2 \pm 0.4$ ppmv, above expected background levels of $<2$ ppmv for a remote location (Farrell et al., 2013; Wofsy et al., 2011), with peak measured concentrations reaching $16.1 \mathrm{ppmv}$ (1 min average). BC concentrations also were elevated for a remote region, with average concentrations of $900 \pm 100 \mathrm{ng} \mathrm{m}^{-3}$. To better demonstrate the direct impact of oil and gas activities on these species in the region, two mobile sampling periods from the Bakken region are shown in Fig. 12. One set of measurements was located on the Indian Hill oil field, where there was an active flare at the time of the measurement. The other set of measurements was located on the Painted Woods oil field, with no active flare. Figure 12a shows the data collected near the Indian Hill location (active flare) where an increase in $\mathrm{CH}_{4}$ concentrations corresponded to high concentrations of $\mathrm{BC}$. During the flaring, maximum $\mathrm{BC}$ concentrations near the site were approximately 4 times higher than the regional BC concentrations. The data collected from the Painted Woods oil field, with no active flare, are shown in Fig. 12b. Without flaring, these measurements show elevated $\mathrm{CH}_{4}$ concentrations ( $\sim 7$ times above the regional background average), with no corresponding increase in the BC. These areas thus provide sources of VOCs, and, when flaring is present, BC.

Using the light alkanes as markers for local oil and gas activities, we compared alkane concentrations to measurements of $\mathrm{NO}_{x}, \mathrm{SO}_{2}$ and $\mathrm{BC}$ throughout the second study period. Timelines of all of these species are shown in Fig. 13 for THRO-N. In the figure, we use ethane as a marker for oil and gas emissions, but all of the light alkanes showed similar results. $\mathrm{NO}_{x}, \mathrm{SO}_{2}$ and $\mathrm{BC}$ concentrations are daily average values; in contrast, ethane data are calculated as the average of two grab samples per day: one collected in the morning (typically 8 a.m.), and one collected in the afternoon (typically 4 p.m.). Concentrations of $\mathrm{NO}_{x}$ and $\mathrm{BC}$ were correlated with ethane (correlation coefficients, $r=0.75$ for $\mathrm{NO}_{x}$ and $r=0.70$ for $\mathrm{BC}$ ) throughout the study period. Although these measurements do not identify which emissions source drives the elevated concentrations for $\mathrm{NO}_{x}$ and $\mathrm{BC}$, the data suggest that VOCs, $\mathrm{NO}_{x}$ and $\mathrm{BC}$ likely have collocated sources. $\mathrm{SO}_{2}$ was not as strongly correlated with ethane $(r=0.42)$. The lower correlation is presumably because $\mathrm{SO}_{2}$ comes largely from different sources, as discussed above.

Measurements collected at THRO-N as part of the first intensive study (February-April 2013) also showed that $\mathrm{NO}_{x}$ and EC were correlated (Fig. 7; $r=0.81$ for $1 \mathrm{~h}$ data) with elevated concentrations observed throughout the campaign. Although we did not make routine measurements of VOCs during the first study period, we expect that these measurements were likely impacted by similar sources as observed in the second study period; i.e. oil and gas related emissions. Hourly $\mathrm{NO}_{x}$ and EC concentrations reached $10 \mathrm{ppbv}$ and $1.3 \mu \mathrm{g} \mathrm{m}^{-3}$, respectively, during the first study period; the maximum observed hourly $\mathrm{SO}_{2}$ concentration was just over 9 ppbv. As discussed above, higher concentrations for all 

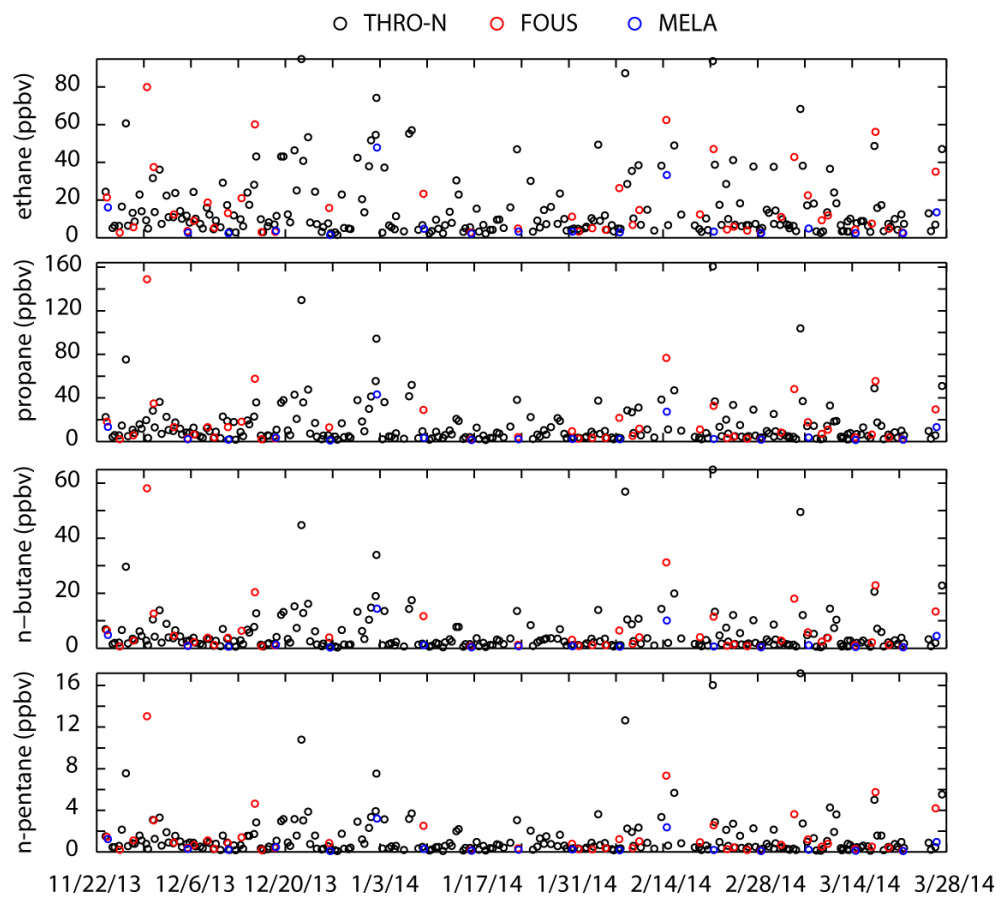

Figure 10. Timeline of light alkane concentrations at THRO-N, FOUS and MELA during the second study period (November 2013March 2014). All data are from grab samples.

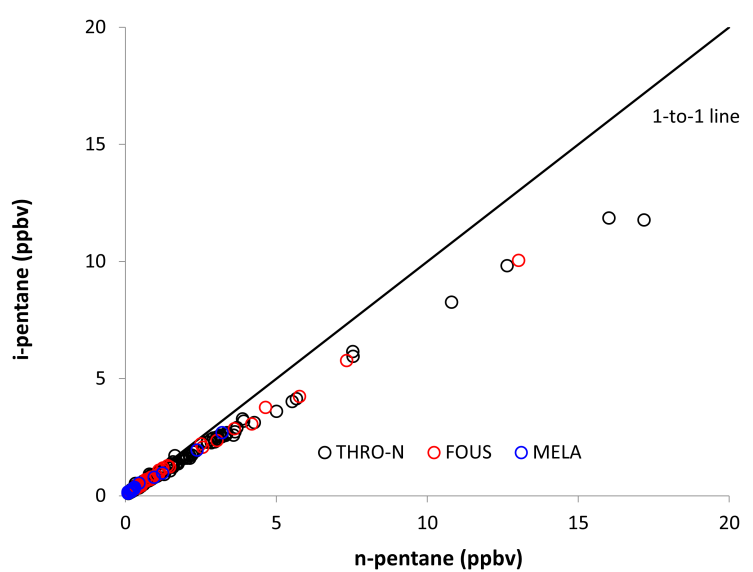

Figure 11. Ratio of iso- to n-pentane for canister samples collected at THRO-N, FOUS, and MELA throughout the second study period.

species typically were observed during periods of low wind speeds and changing wind directions. Such conditions allow pollutants to accumulate in the region, particularly those with local sources.

The data shown thus far suggest that emissions from oil and gas activities are impacting air quality in the region, raising ambient concentrations of VOCs, $\mathrm{NO}_{x}$, and EC. Next, we use VOC measurements to estimate the amount of photochemical processing within the air masses that reached THRO-N during the study. To this end, we use the alkyl ni- trate to parent hydrocarbon ratios $\left(\mathrm{R}-\mathrm{ONO}_{2} / \mathrm{R}-\mathrm{H}\right)$ to estimate air mass age for measurements at THRO-N (e.g. Bertman et al., 1995; Russo et al., 2010a; Simpson et al., 2003; Swarthout et al., 2013). The modeled ratios of 2-pentyl nitrate to n-pentane versus 2-butyl nitrate to n-butane are presented in Fig. 14 (solid line) along with the measurements of these species. For the model, a diurnally averaged $\mathrm{OH}$ concentration of $5 \times 10^{5}$ molec $\mathrm{cm}^{-3}$ was assumed. The measured ratios fall on the modeled line, suggesting that the photochemical sources of the alkyl nitrates are reasonably well represented in the model. Results indicate a photochemical processing time of $<2$ days throughout the majority of the campaign. These results are similar to wintertime VOC measurements in the Denver-Julesburg basin in NE Colorado (Swarthout et al., 2013). For a windspeed of $1.44 \mathrm{~m} \mathrm{~s}^{-1}$, the median windspeed observed at THRO-N during the second study, a processing time of 2 days corresponds to a transport distance of $\sim 250 \mathrm{~km}$. Because the absolute air mass age determined from the estimates are $\mathrm{OH}$ radical concentration dependent, these estimates are subject to uncertainty. However, the results show that processes are occurring on relatively short timescales and are associated with fresh emissions, rather than aged air masses, and so point to emissions within the Bakken, rather than long-range transport from other oil and gas basins. $\mathrm{NO}_{x}$ and $\mathrm{BC}$ concentrations also are shown on the alkyl nitrate evolution plots in Fig. 14a and b, respectively. These data show that the highest levels of $\mathrm{NO}_{x}$ and $\mathrm{BC}$ occur in air masses with short processing times $(<12 \mathrm{~h})$, 

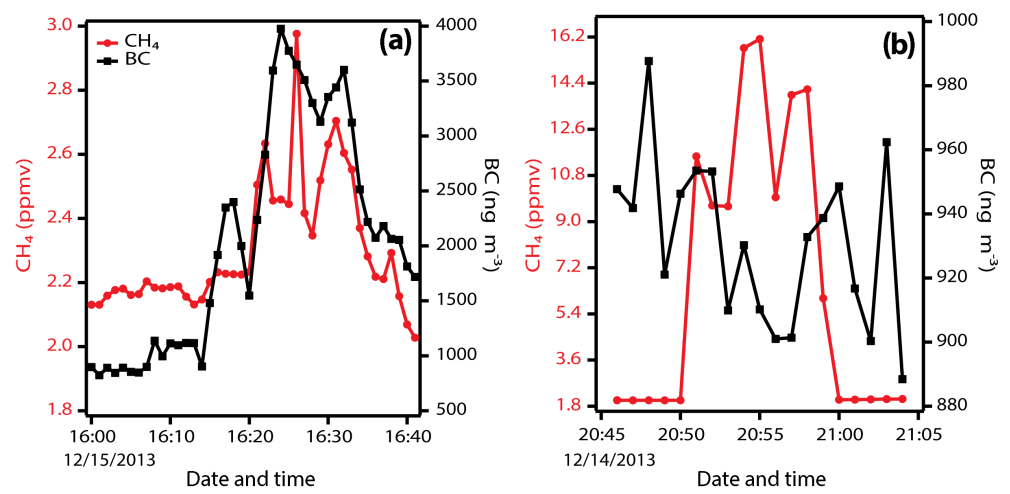

Figure 12. Concentrations of $\mathrm{CH}_{4}(\mathrm{ppmv})$ and $\mathrm{BC}\left(\mathrm{ng} \mathrm{m}^{-3}\right)$. (a) Measurements collected near a well with an active flare at Indian Hill; and (b) measurements collected downwind of a site in Painted Woods oil field, with multiple well-heads and collection tanks, but no flare. Note the difference in scale for the two plots.

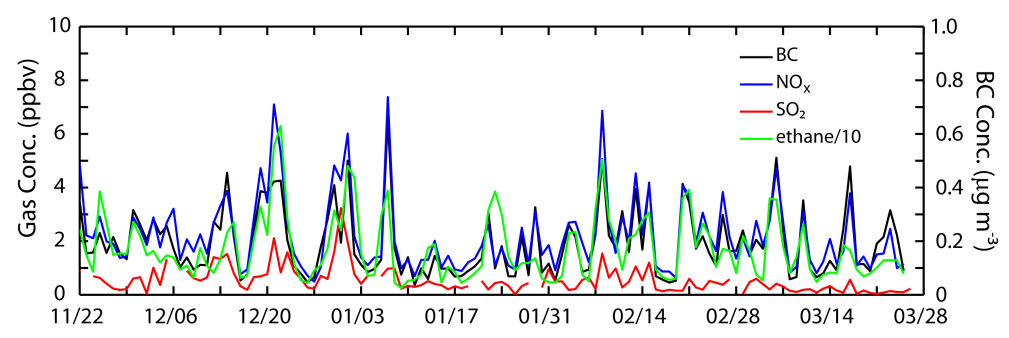

Figure 13. Timeline of ethane, $\mathrm{NO}_{x}, \mathrm{SO}_{2}$, and $\mathrm{BC}$ during the second study period in 2013-2014. $\mathrm{NO}_{x}, \mathrm{SO}_{2}$ and $\mathrm{BC}$ concentrations are daily average values; ethane data are the average of two grab samples per day, one collected in the morning and one collected in the afternoon.

consistent with the data presented thus far, and further implicating local sources for $\mathrm{NO}_{x}$ and $\mathrm{BC}$; this is particularly relevant for $\mathrm{BC}$, which has a longer atmospheric lifetime. A similar plot is shown for $\mathrm{SO}_{2}$ in Fig. S3.

\section{EC concentrations and well counts}

If we assume that THRO-S is representative of background aerosol changes, as discussed above, then the ratio of concentrations from surrounding sites relative to THRO-S represents the influence of changing emissions from local sources. As such, we compared the ratio of concentrations from several sites relative to THRO-S, for species monitored as part of the IMPROVE network. For EC measurements made since 2000, all regional IMPROVE sites north of THRO-S show significant increases relative to THRO-S, while regional IMPROVE sites to the south show decreases relative to THRO-S (Fig. S4 in the Supplement). These data are consistent with improving regional air quality, and increasing EC sources north of THRO-S, likely from flaring, diesel traffic, and the many diesel engines used in oil and gas activities. THRO-S is likely impacted some from local emissions, but there is a clear gradient in EC trends (Figs. S1 and S4). Nitrate shows a similar pattern to EC, with sites to the north increasing relative to THRO-S, and sites to the south decreasing relative to THRO-S. In the case of nitrate, however, not all of these trends are statistically significant. Unlike EC, the trends in nitrate are confounded by the fact that nitrate is not a primary emission and the monitoring sites are very near the source of precursor $\mathrm{NO}_{x}$. The ability of $\mathrm{NO}_{x}$ emitted from oil and gas activities to form ammonium nitrate particles, after being converted to $\mathrm{HNO}_{3}$, also depends on the availability of background ammonia (Li et al., 2014).

Focusing on EC, Fig. 15 presents a timeline of the ratios of EC concentrations from Fig. S4 for two sites north of THRO-S (LOST and MELA), plotted along with data corresponding to oil and gas activities in the region, represented by the number of wells within $100 \mathrm{~km}$ of the site of interest. A distance of $100 \mathrm{~km}$ was chosen to limit the comparison to development in the Bakken region (see Fig. 1). Of the wells that were within $100 \mathrm{~km}$, wells were weighted according to distance from the site as $1 /$ distance, in $\mathrm{km}$, to account for the greater contributions of wells nearer to the sampling sites. For example, a well that is located $1 \mathrm{~km}$ from the site would be weighted as 1 well $/ 1 \mathrm{~km}=1$ well; whereas a well which is $100 \mathrm{~km}$ from the site would be weighted as 1 well $/ 100 \mathrm{~km}=0.010$ well. Well data were downloaded in February 2015 from the relevant state and provincial websites for ND, SD, MT, Saskatchewan and Manitoba. These websites provide different milestone dates from which the years that the wells were completed were estimated. For example, ND includes spud date, while MT includes well com- 

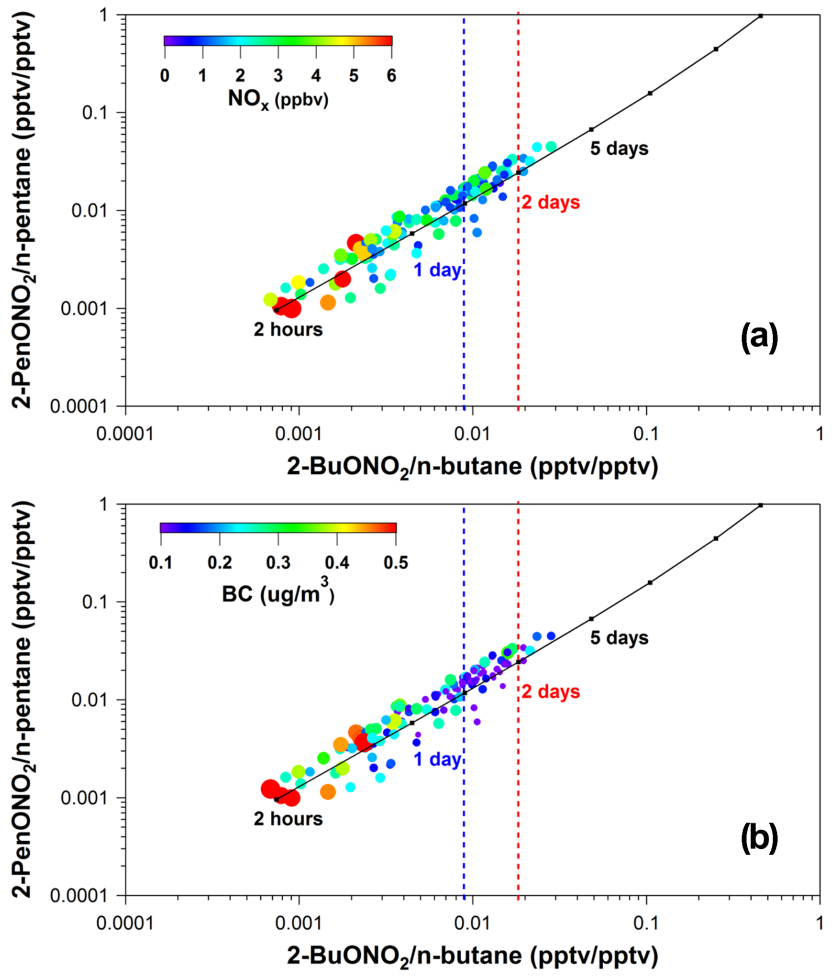

Figure 14. A photochemical clock utilizing ratios of alkyl nitrates to n-alkanes. Modeled ratios are shown as the solid line, and measured data are given as points, colored and sized by daily averaged (a) $\mathrm{NO}_{x}$ and (b) $\mathrm{BC}$ concentrations.

pletion date. Data also were filtered to include only wells that were active and/or producing at the time of the download; as such, wells that were active at an earlier date, but were plugged prior to 2015, were not included. Despite these shortcomings, these data provide a reasonable estimate for the year in which wells began operation. As indicated in Fig. 15, at both sites we observe an increase in EC concentrations at the given site, relative to THRO-S, corresponding to increases in regional oil and gas activities, as designated by well counts. This increase is more evident at LOST, where there is more oil and gas development. For MELA, there is a much smaller increase in EC, relative to THRO-S, corresponding to fewer wells. For both sites, most of the changes occur after about 2008, when oil and gas activities accelerated, further suggesting that oil and gas activities are impacting air quality in national parks and Class 1 areas in the region.

\section{Summary and conclusions}

Over the past 10 years, the Bakken region has seen a tremendous increase in oil and gas extraction, such that North Dakota is now the second leading oil producing state in the United States (www.eia.gov). Combined with decreasing
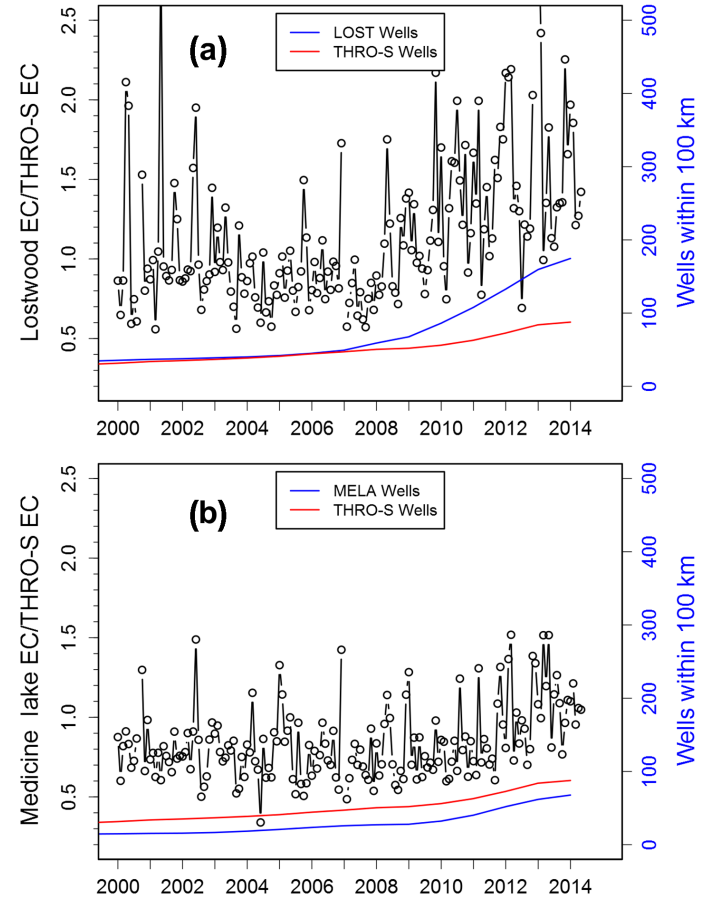

Figure 15. Timeline of ratios of EC concentration at (a) LOST, and (b) MELA, relative to THRO-S. Also shown are data representing wells within $100 \mathrm{~km}$ of the given site, weighted by distance, and wells within $100 \mathrm{~km}$ of THRO-S. EC data are shown as monthly averages, while data for well counts are annual averages to better account for the uncertainty in the dates when wells began operation.

emissions from power plants, new emissions sources related to oil and gas activities are playing an increasingly important role in regional air quality. In response to these changes, the Bakken Air Quality Study was conducted to better characterize the impact of these changing emissions sources on federal lands in the region. Measurements were carried out at multiple sites during two study periods (February-April 2013; November 2013-March 2014), along with mobile measurements made throughout the region during select time periods.

Results from BAQS demonstrate that oil and gas emissions are impacting air quality at THRO, FOUS, MELA and LOST, with larger effects observed in those areas near the most extensive oil and gas development. The impacts include higher ambient concentrations of VOCs, $\mathrm{NO}_{x}$ and $\mathrm{EC}$, offsetting some of the benefits from decreased power plant emissions. Although the observed concentrations fall well below the National Ambient Air Quality Standards, they are elevated for a remote area, and in some cases are increasing. Continued development is expected to exacerbate these problems, particularly during periods when lower wind speeds allow pollutants to accumulate and react in the atmosphere, forming secondary pollutants. Stagnant air conditions have also been associated with health impacts in regions with unconventional natural gas development (Brown et al., 2015). 
New state regulations are in place to reduce emissions from flaring, a potentially major source of pollutants in the area. However, even if flaring goals are met by 2020 , up to $10 \%$ of the produced gas will still be flared, far exceeding the national average. As such, efforts to identify further reductions in emissions are needed to ensure that air quality in federal lands in the region remains unimpaired for the enjoyment of future generations.

\section{The Supplement related to this article is available online at doi:10.5194/acp-16-1401-2016-supplement.}

Acknowledgements. This project was funded by the National Park Service. The CSU portion of the work was funded by Cooperative Agreement H2370094000, Task Agreement P13AC01187. The authors wish to thank the staffs at THRO, FOUS, MELA, and KNRI for site access and logistical support throughout the study. The assumptions, findings, conclusions, judgments, and views presented herein are those of the authors and should not be interpreted as necessarily representing the NPS. IMPROVE Data: IMPROVE is a collaborative association of state, tribal, and federal agencies, and international partners. US Environmental Protection Agency is the primary funding source, with contracting and research support from the National Park Service. The Air Quality Group at the University of California, Davis is the central analytical laboratory, with ion analysis provided by Research Triangle Institute, and carbon analysis provided by Desert Research Institute. EPA AirData: US Environmental Protection Agency. Air Quality System Data Mart [internet database] available at http://www.epa.gov/ttn/airs/aqsdatamart (accessed 17 February 2015).

Edited by: S. Brown

\section{References}

Ahmadov, R., McKeen, S., Trainer, M., Banta, R., Brewer, A., Brown, S., Edwards, P. M., de Gouw, J. A., Frost, G. J., Gilman, J., Helmig, D., Johnson, B., Karion, A., Koss, A., Langford, A., Lerner, B., Olson, J., Oltmans, S., Peischl, J., Pétron, G., Pichugina, Y., Roberts, J. M., Ryerson, T., Schnell, R., Senff, C., Sweeney, C., Thompson, C., Veres, P. R., Warneke, C., Wild, R., Williams, E. J., Yuan, B., and Zamora, R.: Understanding high wintertime ozone pollution events in an oil- and natural gasproducing region of the western US, Atmos. Chem. Phys., 15, 411-429, doi:10.5194/acp-15-411-2015, 2015.

Bamberger, M. and Oswald, R. E.: Long-term impacts of unconventional drilling operations on human and animal health, J. Environ. Sci Heal. A, 50, 447-459, doi:10.1080/10934529.2015.992655, 2015.

Bar-Ilan, A., Grant, J., Parikh, R., Morris, R., and Henderer D.: Oil and Gas Mobile Sources Pilot Study: Final report, 41 pp., 2011.
Benedict, K. B., Day, D., Schwandner, F. M., Kreidenweis, S. M., Schichtel, B., Malm, W. C., and Collett, J. L.: Observations of atmospheric reactive nitrogen species in Rocky Mountain National Park and across northern Colorado, Atmos. Environ., 64, 66-76, doi:10.1016/j.atmosenv.2012.08.066, 2013.

Bertman, S. B., Roberts, J. M., Parrish, D. D., Buhr, M. P., Goldan, P. D., Kuster, W. C., Fehsenfeld, F. C., Montzka, S. A., and Westberg, H.: Evolution of alkyl nitrates with air-mass age, J. Geophys. Res.-Atmos., 100, 22805-22813, doi:10.1029/95jd02030, 1995.

Brandt, A. R., Heath, G. A., Kort, E. A., O’Sullivan, F., Petron, G., Jordaan, S. M., Tans, P., Wilcox, J., Gopstein, A. M., Arent, D., Wofsy, S., Brown, N. J., Bradley, R., Stucky, G. D., Eardley, D., and Harriss, R.: Methane Leaks from North American Natural Gas Systems, Science, 343, 733-735, doi:10.1126/science.1247045, 2014.

Brown, D. R., Lewis, C., and Weinberger, B. I.: Human exposure to unconventional natural gas development: A public health demonstration of periodic high exposure to chemical mixtures in ambient air, J. Environ. Sci Heal. A, 50, 460-472, doi:10.1080/10934529.2015.992663, 2015.

Bytnerowicz, A., Fraczek, W., Schilling, S., and Alexander, D.: Spatial and temporal distribution of ambient nitric acid and ammonia in the Athabasca Oil Sands Region, Alberta, J. Limnol., 69, 1121, doi:10.4081/jlimnol.2010.s1.11, 2010.

Cai, J., Yan, B. Z., Ross, J., Zhang, D. N., Kinney, P. L., Perzanowski, M. S., Jung, K., Miller, R., and Chillrud, S. N.: Validation of MicroAeth (R) as a Black Carbon Monitor for Fixed-Site Measurement and Optimization for Personal Exposure Characterization, Aerosol Air Qual. Res., 14, 1-9, doi:10.4209/aaqr.2013.03.0088, 2014.

Carlton, A. G., Little, E., Moeller, M., Odoyo, S., and Shepson, P. B.: The data gap: Can a lack of monitors obscure loss of Clean Air Act benefits in fracking areas?, Environ. Sci. Technol., 48, 893-894, doi:10.1021/es405672t, 2014.

Carslaw, D. C.: The openair manual - open-source tools for analysing air pollution data, Manual for version 1.0, King's College London, 2014.

Carslaw, D. C. and Ropkins, K.: openair - an R package for air quality data analysis, Environ. Model. Softw., 27-28, 52-61, 2012.

Colborn, T., Kwiatkowski, C., Schultz, K., and Bachran, M.: Natural Gas Operations from a Public Health Perspective, Hum. Ecol. Risk Assess., 17, 1039-1056, doi:10.1080/10807039.2011.605662, 2011.

Draxler, R. R. and Hess, G. D.: An overview of the HYSPLIT_4 modeling system of trajectories, dispersion, and deposition, Aust. Meteorol. Mag., 47, 295-308, 1998.

Edwards, P. M., Brown, S. S., Roberts, J. M., Ahmadov, R., Banta, R. M., deGouw, J. A., Dube, W. P., Field, R. A., Flynn, J. H., Gilman, J. B., Graus, M., Helmig, D., Koss, A., Langford, A. O., Lefer, B. L., Lerner, B. M., Li, R., Li, S.-M., McKeen, S. A., Murphy, S. M., Parrish, D. D., Senff, C. J., Soltis, J., Stutz, J., Sweeney, C., Thompson, C. R., Trainer, M. K., Tsai, C., Veres, P. R., Washenfelder, R. A., Warneke, C., Wild, R. J., Young, C. J., Yuan, B., and Zamora, R.: High winter ozone pollution from carbonyl photolysis in an oil and gas basin, Nature, 514, 351354, doi:10.1038/nature13767, 2014.

EIA: U.S. Crude Oil and Natural Gas Proved Reserves, 2013, edited by: US Department of Energy, U.S. Energy Information Ad- 
ministration, Washington, D.C., 42, available at: http://www.eia. gov/naturalgas/crudeoilreserves/pdf/usreserves.pdf (last access: April 2015), 2014.

EPA: Guidance for tracking progress under the Regional Haze Rule EPA-454/B-03-004, 96, available at: http://www3.epa. gov/ttnamti1/files/ambient/visible/tracking.pdf (last access: January 2015), 2003.

Farrell, P., Culling, D., and Leifer, I.: Transcontinental methane measurements: Part 1. A mobile surface platform for source investigations, Atmos. Environ., 74, 422-431, doi:10.1016/j.atmosenv.2013.02.014, 2013.

Field, R. A., Soltis, J., and Murphy, S.: Air quality concerns of unconventional oil and natural gas production, Environmental Science-Processes \& Impacts, 16, 954-969, doi:10.1039/c4em00081a, 2014.

Gilman, J. B., Lerner, B. M., Kuster, W. C., and de Gouw, J. A.: Source Signature of Volatile Organic Compounds from Oil and Natural Gas Operations in Northeastern Colorado, Environ. Sci. Technol., 47, 1297-1305, doi:10.1021/es304119a, 2013.

Grant, J., Parikh, R., Bar-Ilan, A., and Morris, R.: Development of baseline 2011 and future year 2015 emissions from oil and gas activity in the Williston Basin: Final report, 103, available at: http://www.wrapair2.org/pdf/2011_2015_ Williston_Basin_14Aug2014.pdf (last access: February 2015), 2014

Hand, J. L., Gebhart, K. A., Schichtel, B. A., and Malm, W. C.: Increasing trends in wintertime particulate sulfate and nitrate ion concentrations in the Great Plains of the United States (2000-2010), Atmos. Environ., 55, 107-110, doi:10.1016/j.atmosenv.2012.03.050, 2012a.

Hand, J. L., Schichtel, B. A., Malm, W. C., and Pitchford, M. L.: Particulate sulfate ion concentration and $\mathrm{SO}_{2}$ emission trends in the United States from the early 1990s through 2010, Atmos. Chem. Phys., 12, 10353-10365, doi:10.5194/acp-1210353-2012, 2012b.

Hand, J. L., Schichtel, B. A., Malm, W. C., Copeland, S., Molenar, J. V., Frank, N., and Pitchford, M.: Widespread reductions in haze across the United States from the early 1990s through 2011, Atmos. Environ., 94, 671-679, doi:10.1016/j.atmosenv.2014.05.062, 2014.

Helmig, D., Thompson, C. R., Evans, J., Boylan, P., Hueber, J., and Park, J. H.: Highly Elevated Atmospheric Levels of Volatile Organic Compounds in the Uintah Basin, Utah, Environ. Sci. Technol., 48, 4707-4715, doi:10.1021/es405046r, 2014.

Howarth, R. W., Santoro, R., and Ingraffea, A.: Methane and the greenhouse-gas footprint of natural gas from shale formations, Climatic Change, 106, 679-690, doi:10.1007/s10584-011-0061$5,2011$.

Howell, S. G., Clarke, A. D., Freitag, S., McNaughton, C. S., Kapustin, V., Brekovskikh, V., Jimenez, J.-L., and Cubison, M. J.: An airborne assessment of atmospheric particulate emissions from the processing of Athabasca oil sands, Atmos. Chem. Phys., 14, 5073-5087, doi:10.5194/acp-14-5073-2014, 2014.

Janjić, Z. I.: A nonhydrostatic model based on a new approach, Meteorol. Atmos. Phys., 82, 271-285, 2003.

Jiang, M., Griffin, W. M., Hendrickson, C., Jaramillo, P., VanBriesen, J., and Venkatesh, A.: Life cycle greenhouse gas emissions of Marcellus shale gas, Environ. Res. Lett., 6, 03414, doi:10.1088/1748-9326/6/3/034014, 2011.
Laden, F., Schwartz, J., Speizer, F. E., and Dockery, D. W.: Reduction in fine particulate air pollution and mortality - Extended follow-up of the Harvard six cities study, Am. J. Resp. Crit. Care, 173, 667-672, doi:10.1164/rccm.200503-443OC, 2006.

Leahey, D. M., Preston, K., and Strosher, M.: Theoretical and observational assessments of flare efficiencies, J. Air Waste Manage., 51, 1610-1616, 2001.

Li, Y., Schwandner, F. M., Sewell, H. J., Zivkovich, A., Tigges, M., Raja, S., Holcomb, S., Molenar, J. V., Sherman, L., Archuleta, C., Lee, T., and Collett, J. L.: Observations of ammonia, nitric acid, and fine particles in a production region, Atmos. Environ., 83, 80-89, doi:10.1016/j.atmosenv.2013.10.007, 2014.

Malm, W. C., Sisler, J. F., Huffman, D., Eldred, R. A., and Cahill, T. A.: Spatial and seasonal trends in particle concentration and optical extinction in the United States, J. Geophys. Res.-Atmos., 99, 1347-1370, doi:10.1029/93jd02916, 1994.

McKenzie, L. M., Witter, R. Z., Newman, L. S., and Adgate, J. L.: Human health risk assessment of air emissions from development of unconventional natural gas resources, Sci. Total Environ., 424, 79-87, doi:10.1016/j.scitotenv.2012.02.018, 2012.

McLinden, C. A., Fioletov, V., Boersma, K. F., Krotkov, N., Sioris, C. E., Veefkind, J. P., and Yang, K.: Air quality over the Canadian oil sands: A first assessment using satellite observations, Geophys. Res. Lett., 39, L04804, doi:10.1029/2011g1050273, 2012.

Mønster, J. G., Samuelsson, J., Kjeldsen, P., Rella, C. W., and Scheutz, C.: Quantifying methane emission from fugitive sources by combining tracer release and downwind measurements - A sensitivity analysis based on multiple field surveys, Waste Manage., 34, 1416-1428, doi:10.1016/j.wasman.2014.03.025, 2014.

Olaguer, E. P.: The potential near-source ozone impacts of upstream oil and gas industry emissions, J. Air Waste Manage., 62, 966977, doi:10.1080/10962247.2012.688923, 2012.

Pederstad, A., Gallardo, M., and Saunier, S.: Improving utilization of associated gas in US tight oil fields, 67 pp., available at: http:// www.catf.us/resources/publications/view/212, last access: April 2015.

Petron, G., Frost, G., Miller, B. R., Hirsch, A. I., Montzka, S. A., Karion, A., Trainer, M., Sweeney, C., Andrews, A. E., Miller, L., Kofler, J., Bar-Ilan, A., Dlugokencky, E. J., Patrick, L., Moore, C. T., Jr., Ryerson, T. B., Siso, C., Kolodzey, W., Lang, P. M., Conway, T., Novelli, P., Masarie, K., Hall, B., Guenther, D., Kitzis, D., Miller, J., Welsh, D., Wolfe, D., Neff, W., and Tans, P.: Hydrocarbon emissions characterization in the Colorado Front Range: A pilot study, J. Geophys. Res.-Atmos., 117, D04304, doi:10.1029/2011jd016360, 2012.

Petzold, A., Ogren, J. A., Fiebig, M., Laj, P., Li, S.-M., Baltensperger, U., Holzer-Popp, T., Kinne, S., Pappalardo, G., Sugimoto, N., Wehrli, C., Wiedensohler, A., and Zhang, X.-Y.: Recommendations for reporting "black carbon" measurements, Atmos. Chem. Phys., 13, 8365-8379, doi:10.5194/acp-13-83652013, 2013.

Prenni, A. J., Levin, E. J. T., Benedict, K. B., Sullivan, A. P., Schurman, M. I., Gebhart, K. A., Day, D. E., Carrico, C. M., Malm, W. C., Schichtel, B. A., Collett, J. L., Jr., and Kreidenweis, S. M.: Gas-phase reactive nitrogen near Grand Teton National Park: Impacts of transport, anthropogenic emissions, and biomass burning, Atmos. Environ., 89, 749-756, doi:10.1016/j.atmosenv.2014.03.017, 2014. 
Rieder, H. E., Fiore, A. M., Polvani, L. M., Lamarque, J. F., and Fang, Y.: Changes in the frequency and return level of high ozone pollution events over the eastern United States following emission controls, Environ. Res. Lett., 8, 014012, doi:10.1088/17489326/8/1/014012, 2013.

Rodriguez, M. A., Barna, M. G., and Moore, T.: Regional Impacts of Oil and Gas Development on Ozone Formation in the Western United States, J. Air Waste Manage., 59, 1111-1118, doi:10.3155/1047-3289.59.9.1111, 2009.

Roy, A. A., Adams, P. J., and Robinson, A. L.: Air pollutant emissions from the development, production, and processing of Marcellus Shale natural gas, J. Air Waste Manage., 64, 19-37, doi:10.1080/10962247.2013.826151, 2014.

Russo, R. S., Zhou, Y., Haase, K. B., Wingenter, O. W., Frinak, E. K., Mao, H., Talbot, R. W., and Sive, B. C.: Temporal variability, sources, and sinks of $\mathrm{C}_{1}-\mathrm{C}_{5}$ alkyl nitrates in coastal New England, Atmos. Chem. Phys., 10, 1865-1883, doi:10.5194/acp10-1865-2010, 2010a.

Russo, R. S., Zhou, Y., White, M. L., Mao, H., Talbot, R., and Sive, B. C.: Multi-year (2004-2008) record of nonmethane hydrocarbons and halocarbons in New England: seasonal variations and regional sources, Atmos. Chem. Phys., 10, 4909-4929, doi:10.5194/acp-10-4909-2010, 2010 b.

Schneising, O., Burrows, J. P., Dickerson, R. R., Buchwitz, M., Reuter, M., and Bovensmann, H.: Remote sensing of fugitive methane emissions from oil and gas production in North American tight geological formations, Earth's Future, 2, 548-558, doi:10.1002/2014EF000265, 2014.

Schnell, R. C., Oltmans, S. J., Neely, R. R., Endres, M. S., Molenar, J. V., and White, A. B.: Rapid photochemical production of ozone at high concentrations in a rural site during winter, Nat. Geosci., 2, 120-122, doi:10.1038/ngeo415, 2009.

Sen, P. K.: Estimates of the regression coefficient based on Kendall's tau, J. Am. Stat. Assoc., 63, 1379-1389, 1968.

Sickles II, J. E. and Shadwick, D. S.: Air quality and atmospheric deposition in the eastern US: 20 years of change, Atmos. Chem. Phys., 15, 173-197, doi:10.5194/acp-15-173-2015, 2015.

Simpson, I. J., Blake, N. J., Blake, D. R., Atlas, E., Flocke, F., Crawford, J. H., Fuelberg, H. E., Kiley, C. M., Meinardi, S., and Rowland, F. S.: Photochemical production and evolution of selected $\mathrm{C}_{2}-\mathrm{C}_{5}$ alkyl nitrates in tropospheric air influenced by Asian outflow, J. Geophys. Res.-Atmos., 108, 8808, doi:10.1029/2002jd002830, 2003.

Simpson, I. J., Blake, N. J., Barletta, B., Diskin, G. S., Fuelberg, H. E., Gorham, K., Huey, L. G., Meinardi, S., Rowland, F. S., Vay, S. A., Weinheimer, A. J., Yang, M., and Blake, D. R.: Characterization of trace gases measured over Alberta oil sands mining operations: 76 speciated $\mathrm{C}_{2}-\mathrm{C}_{10}$ volatile organic compounds (VOCs), $\mathrm{CO}_{2}, \mathrm{CH}_{4}, \mathrm{CO}, \mathrm{NO}, \mathrm{NO}_{2}, \mathrm{NO}_{y}, \mathrm{O}_{3}$ and $\mathrm{SO}_{2}$, Atmos. Chem. Phys., 10, 11931-11954, doi:10.5194/acp10-11931-2010, 2010.
Sive, B. C.: Atmospheric nonmethane hydrocarbons: Analytical methods and estimated hydroxyl radical concentrations, University of California, Irvine, 1998.

Steinzor, N., Subra, W., and Sumi, L.: Investigating links between shale gas development and health impacts through a community survey project in Pennsylvania, New Solutions, 23, 55-83, 2013.

Subramanian, R., Williams, L. L., Vaughn, T. L., Zimmerle, D., Roscioli, J. R., Herndon, S. C., Yacovitch, T. I., Floerchinger, C., Tkacik, D. S., Mitchell, A. L., Sullivan, M. R., Dallmann, T. R., and Robinson, A. L.: Methane Emissions from Natural Gas Compressor Stations in the Transmission and Storage Sector: Measurements and Comparisons with the EPA Greenhouse Gas Reporting Program Protocol, Environ. Sci. Technol., 49, 32523261, doi:10.1021/es5060258, 2015.

Swarthout, R. F., Russo, R. S., Zhou, Y., Hart, A. H., and Sive, B. C.: Volatile organic compound distributions during the NACHTT campaign at the Boulder Atmospheric Observatory: Influence of urban and natural gas sources, J. Geophys. Res.-Atmos., 118, 10614-10637, doi:10.1002/jgrd.50722, 2013.

Swarthout, R. F., Russo, R. S., Zhou, Y., Miller, B. M., Mitchell, B., Horsman, E., Lipsky, E., McCabe, D. C., Baum, E., and Sive, B. C.: Impact of Marcellus Shale Natural Gas Development in Southwest Pennsylvania on Volatile Organic Compound Emissions and Regional Air Quality, Environ. Sci. Technol., 49, 31753184, doi:10.1021/es504315f, 2015.

Theil, H.: A rank-invariant method of linear and polynomial regression analysis, I, II and III, Proceedings of the Koninklijke Nederlandse Akademie Wetenschappen, Series A - Mathematical Sciences, Statistical Department of the "Mathematisch Centrum", Amsterdam, the Netherlands, 50, 386-392, 521-525, 1397-1412, 1950.

Wofsy, S. C., Team, H. S., Cooperating Modellers, T., and Satellite, T.: HIAPER Pole-to-Pole Observations (HIPPO): finegrained, global-scale measurements of climatically important atmospheric gases and aerosols, Philos. T. Roy. Soc. A, 369, 20732086, doi:10.1098/rsta.2010.0313, 2011.

Zhou, Y., Shively, D., Mao, H., Russo, R. S., Pape, B., Mower, R. N., Talbot, R., and Sive, B. C.: Air Toxic Emissions from Snowmobiles in Yellowstone National Park, Environ. Sci. Technol., 44, 222-228, doi:10.1021/es9018578, 2010. 